Article

\title{
Ranking Potential Renewable Energy Systems to Power On-Farm Fertilizer Production
}

\author{
Ali Mostafaeipour 1,2,3, Ali Sadeghi Sedeh ${ }^{4}$, Shahariar Chowdhury 3,5 (i) \\ and Kuaanan Techato ${ }^{3,5, *}$ \\ 1 Institute of Research and Development, Duy Tan University, Da Nang 550000, Vietnam; \\ alimostafaeipour@duytan.edu.vn \\ 2 The Faculty of Civil Engineering, Duy Tan University, Da Nang 550000, Vietnam \\ 3 Department of Sustainable Energy, Faculty of Environmental Management, Prince of Songkla University, \\ 90110 Songkhla, Thailand; Engshahariar@live.com \\ 4 Industrial Engineering Department, Yazd University, Yazd 89195741, Iran; alisadeghi7595@gmail.com \\ 5 Environmental Assessment and Technology for Hazardous Waste Management Research Center, Faculty of \\ Environmental Management, Prince of Songkla University, 90110 Songkhla, Thailand \\ * Correspondence: Kuaanan.t@psu.ac.th; Tel.: +66-8-184-189-62
}

Received: 17 August 2020; Accepted: 18 September 2020; Published: 23 September 2020

check for updates

\begin{abstract}
Farmers across the world have long used chemical fertilizers to achieve higher production outputs. One of the basic inputs for the production of nitrogen fertilizer is fossil fuel, which is not only finite but also has tangible impacts on the environment. This study aims to determine the most suitable renewable energy resource (RER) for the production of fertilizer in Iranian farmlands. The resources considered in this study were photovoltaic energy, biomass energy, wind energy, and solar thermal energy. This assessment was carried out in terms of six general criteria derived from a PESTEL (Political, Economic, Socio-cultural, Technological, Environmental and Legal) analysis, and thus 20 sub-criteria were obtained with the help of experts. The criteria were weighted using the Fuzzy AHP (Analytic Hierarchy Process) method. Because of the use of criteria with crisp, fuzzy, and interval-type values, the ranking was performed using the extended TODIM (an acronym in Portuguese of interactive and multi-criteria decision-making) method. A sensitivity analysis was performed to determine the effects of the sub-criteria on the results. The results showed that the technological criterion is the most important measure for this assessment, and that photovoltaic energy and wind energy are the top two options for powering chemical fertilizer production in Iranian farmlands.
\end{abstract}

Keywords: fertilizer production; clean energy; prioritizing; farmlands; sensitivity analysis

\section{Introduction}

Energy is one of the most important elements of sustainability and social welfare in many countries in the world [1]. Given the finite nature of fossil fuels and their adverse effects on our natural environment, including global warming and environmental pollution, it is now more important than ever to promote renewable energy generation and consumption as a coherent policy, with the purposes of improving energy security, climate protection and sustainable economic development $[2,3]$. According to the United States Energy Association, renewable energy is an energy that is constantly being produced in nature. Renewable energy is sustainable in many countries around the world, and it could help to combat climate change, environmental pollution, global warming, and many other negative effects [4]. Many developed and developing countries have adopted specific policies to promote the use of renewable energy resources such as wind, solar, thermal, biomass, geothermal, 
and hydropower, etc. [5]. There are many factors which promote and encourage the use of renewable energies: the lack of greenhouse gas emissions from fossil fuels; the reduction of some types of air pollution; and the creation of economic development and jobs in manufacturing, installation, and more. With increasing technological development, renewable energies are having a high impact. More scientists are finding creative and efficient methods of producing renewable energies to meet the increasing demand for energy.

In 2012, Iran's share of global renewable energy consumption was 0.7\% [6]. Iran has excellent renewable energy potential, which can contribute to the more sustainable and faster development of this country. A good example of the use of renewable energy is in the production of ammonia, which is a basic input in many industries, including the production of fertilizers, explosives, and plastics [7]. Sustainable ammonia production has been the subject of several studies, including a study by Alfian and Purwanto [8], where they introduced a strategy for producing green urea using a multi-objective optimization model with the objective of minimizing the production costs and environmental impacts. Arora et al. [9] compared the economic and environmental potential of modern biomass-based ammonia production methods in different countries. Bicer et al. [10] evaluated four different ammonia production methods using the Life Cycle Assessment method. Du et al. [11] conducted a technical simulation and evaluation regarding the production of chemical fertilizer in cornfields with solar power. Morgan et al. [12] assessed the prospects of producing ammonia in remote areas and islands with wind energy. Casallas et al. [13] conducted an experimental study on the electrochemical synthesis of ammonia, and improved this process. They also presented an energy system that uses photovoltaic technology and thermal collectors in combination with fuel cell components. Tallaksen et al. [14] compared wind-powered ammonia production with the production of nitrogen fertilizers using fossil fuels. Palys et al. [15] used a supply chain optimization problem to assess the benefits of ammonia production with modular renewable energy sources.

With the rising number of economically and technologically feasible renewable energy resources, choosing a resource from the range of options has become difficult. In fact, choosing a renewable energy resource for a country is an important and strategic decision with a great number of criteria. To find a safe, efficient and sustainable option for a region, it is often necessary to consider both quantitative and qualitative parameters in the decision making process [16].

Fertilizer production systems have the potential to be green. In the literature, few studies have been conducted on green fertilizer production [11,17]. In this study, a comparative evaluation of renewable energy resources in the chemical fertilizer industry was conducted according to different criteria for fertilizer production in agricultural fields in Iran.

This study uses a Multi Criteria Decision Making (MCDM) model based on crisp, interval and fuzzy numbers to rank renewable energy resources for the production of fertilizer in Iranian farmlands. The purpose of this study is to introduce a hybrid model consisting of PESTEL (Political, Economical, Social, Technological, Environmental and Legal) analysis in order to determine the suitable criteria for evaluation, the Fuzzy AHP (Analytic Hierarchy Process) method to weight the criteria, and extended TODIM (an acronym in Portuguese of interactive and multi-criteria decision-making) to rank the options, for the evaluation of different renewable methods of powering on-site fertilizer production in farmlands. These resources include photovoltaic energy, biomass energy, wind energy, and solar thermal energy. The on-site ammonia production leads to reduced emissions from the ammonia and nitrogen synthesis, as well as decreased negative impacts from the transportation of materials from the production centers to the farmlands.

The steps of this article are as follows:

1. The introduction of a hybrid model (PESTEL, Fuzzy AHP, and Extended TODIM) for ranking renewable energy resources in Iran,

2. The determination of the suitable sub-criteria for the evaluation of renewable energy resources for fertilizer production in Iran (though it could be used for any country).

3. The determination of the suitable renewable energy resources for powering farmlands in Iran. 
4. The proposition of a renewably-powered system for nitrogen fertilizer production in farmlands for the first time in Iran.

This paper is structured as follows: in the next section, the method of fertilizer production in farmlands is described in detail. Section 3 introduces the study area. Section 4 describes the methodology and the proposed models. The results of the models are presented in Section 5, and lastly, Section 6 presents the conclusions and some suggestions for future work.

\section{Green Production Pathway}

\subsection{Chemical Fertilizer}

Fertilizers can be considered as food for plants. They help farmers to feed the world's growing population. Plants need 17 types of nutrients to survive and grow. Fertilizers return the nutrients to the soil after each harvest [18]. Currently, the fertilizer industry accounts for $77 \%$ of the global nitrogen demand [19]. In recent years, this industry has seen consistent progress in productivity and technological innovation [20]. The global demand for nitrogen fertilizers has risen from 111.4 million tons in 2013 to 113.1 million tons in 2014 (1.5\% growth). In 2018, this figure reached 119.4 million tons. About $58 \%$ of this 6.3 million ton increase in demand between 2014 and 2018 is related to Asia, $22 \%$ is related to America, $11 \%$ is related to Europe, $8 \%$ is related to Africa, and 1\% is related to Oceania [21] (Figure 1). Asia had the highest and Western Europe had the lowest share in the increase. Due to the high consumption of fertilizer in Asia, this issue is very important in this region. Although the most common way of producing urea and nitrogen chemical fertilizers is to use hydrocarbons, renewable energy resources can also be used for this purpose, in which case the product is called green fertilizer. These methods are expected to be widely used in the future [22].

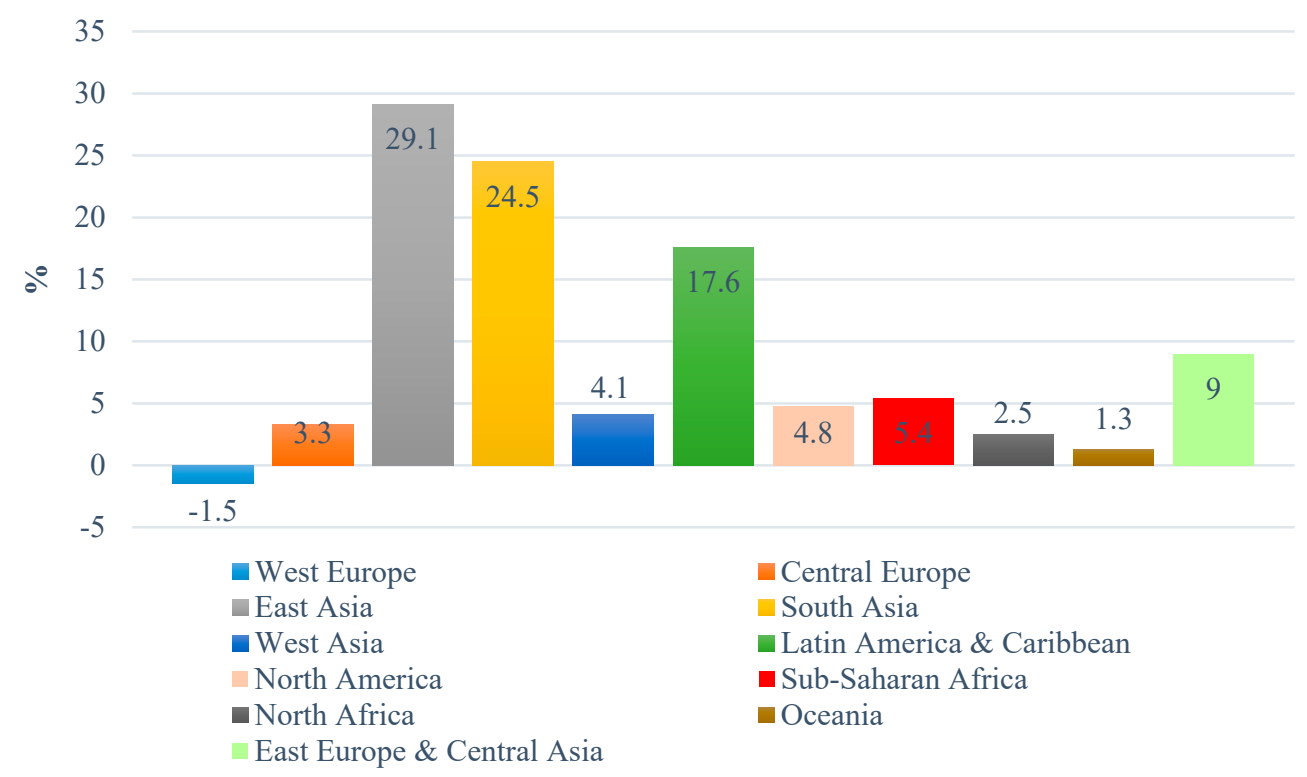

Figure 1. Regional and sub-regional share of the world increase/decrease in nitrogen fertilizer consumption, 2014-2018 [21].

Given the poor soil fertility in most of the cultivatable land in Iran, fertilizers are a necessity for the Iranian agricultural sector. The low rainfall in the country also adds to the importance of using fertilizers to increase the agricultural output. About 6 million tons of nitrogen fertilizers are produced annually in Iran, of which 1.7 million tons are for domestic use and the rest is for export. According to the Iranian Ministry of Agriculture, about 50\% of the fertilizer used inside the country is produced by the private sector. It was predicted that, from 2015 to 2020, the fertilizer market in Iran would grow 
by more than $3.5 \%$, because of the need to improve the yield of agricultural lands. [23]. Fertilizer consumption in Iran (in kilograms per hectare of agricultural land) has fluctuated from 2004 to 2016 due to changes in fertilizer prices, droughts, the use of alternative fertilizers, and reduced numbers of farmers (Figure 2).

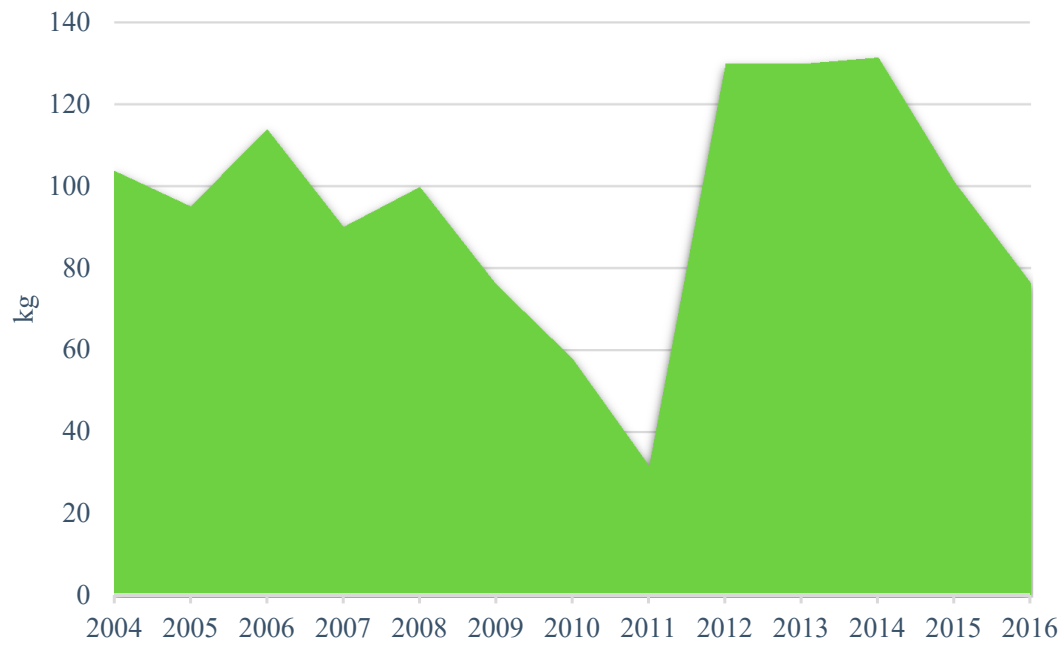

Figure 2. Iran's fertilizer consumption in kg per hectare of arable land (2004-2016) [24].

The most important step in the process of producing nitrogen fertilizer is the synthesis of ammonia, which accounts for $1 \%$ of the world's total energy consumption [11].

\subsection{Ammonia Synthesis}

Ammonia is one of the most abundantly produced chemical substances in the world [25]. The production of ammonia is one of the world's most important industries. Without ammonia-based products and chemical fertilizers, the world's population would be at least 2-3 billion lower than what it is today. As shown in Figure 3, worldwide ammonia production amounted to 166 million tons in 2011, and over 196 million tons at the end of 2017; this means that the production of this material grew by more than $18 \%$ in 7 years. It has been estimated that the ammonia produced annually is worth more than 100 billion dollars. Some ammonia producers produce more than 3,000 Mt/day [26]. With the increasing consumption of ammonia in the world, the $\mathrm{CO}_{2}$ emissions associated with the production and transport of ammonia have become quite significant [27]. It has been estimated that global ammonia production has led to the emission of $289.8 \mathrm{Mt}$ of CO2. The production of ammonia accounts for about $1.5 \%$ of global $\mathrm{CO}_{2}$ emissions [25]. In addition to its extensive use in fertilizer production, ammonia is also used as a fuel [28].

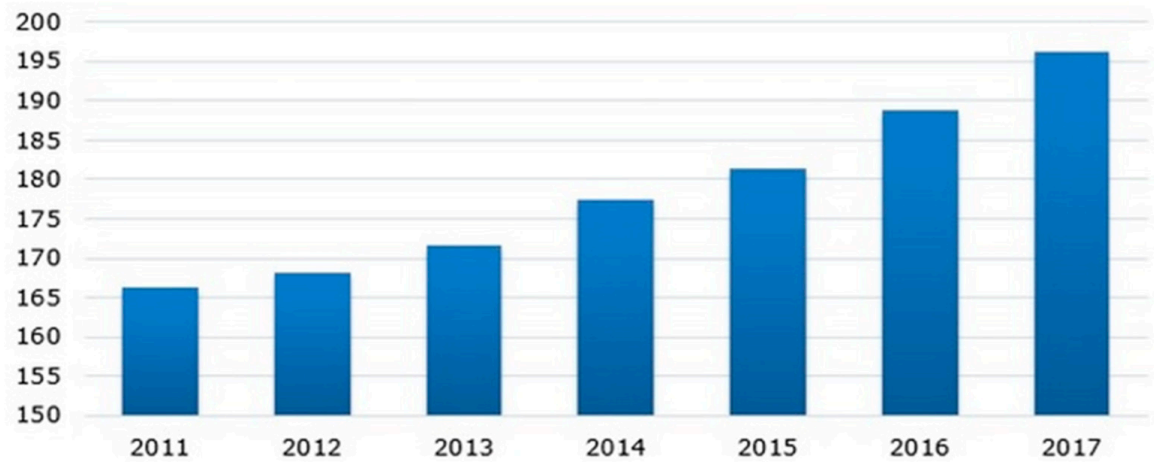

Figure 3. Worldwide ammonia production has steadily increased from 2011-2017 (in million tons) [29]. 
The most commonly used ammonia synthesis method is the Haber-Bosch method [30]. Introduced in the twentieth century, this process produces ammonia by combining air nitrogen with hydrogen. Today, $90 \%$ of all of the ammonia produced in the world is still synthesized by this method. The Haber-Bosch process accounts for $3-5 \%$ of the world's annual natural gas consumption, which is equal to $1-2 \%$ of the world's total annual energy consumption [31].

In order to produce the nitrogen needed for ammonia (NH3), the nitrogen (N2) of the air (air membrane system) can be separated through a cryogenic process. Pure nitrogen can be produced by three main methods: cryogenic distillation, Pressure Swing Absorption (PSA) and membrane separation. Among these methods, cryogenic distillation produces the purest product with the least energy consumption [12]. The hydrogen needed for this process can be produced by the electrolysis of water. The Haber-Bosch process combines hydrogen and nitrogen with an iron oxide catalyst under very low pressure and a moderate temperature [18,32].

$$
\mathrm{N}_{2}(g)+3 \mathrm{H}_{2}(g) \rightarrow 2 \mathrm{NH}_{3}(g)
$$

In the ammonia converter, nitrogen and hydrogen are compressed in order to initiate a reaction and produce ammonia. The ammonia produced in this reaction is a nitrogen fertilizer that, in many cases, is directly injected into the soil. This ammonia can also be used to produce other nitrogen fertilizers. For example, a reaction with $\mathrm{CO}_{2}$ turns this ammonia into a urea fertilizer [33]. Because of its high nitrogen content $(46 \%)$, low cost, and ease of use, urea is the world's most widely used chemical fertilizer. When injected into the soil, it undergoes a series of biological, chemical, and physical changes which produce the essential nutrients for plants [34]. The carbon dioxide required to produce urea can be obtained from the by-products of ammonia plants or the burning of fuel in power plants [8].

The reaction of urea synthesis from ammonia $\left(\mathrm{NH}_{3}\right)$ and carbon dioxide $\left(\mathrm{CO}_{2}\right)$ is shown below.

$$
\mathrm{CO}_{2}+2 \mathrm{NH}_{3} \leftrightarrows \mathrm{NH}_{2} \mathrm{COONH}_{4} \leftrightarrows \mathrm{NH}_{2} \mathrm{CONH}_{2}+\mathrm{H}_{2} \mathrm{O}
$$

\subsection{Hydrogen}

Hydrogen production is an important and critical process for the synthesis of ammonia [25]. Although hydrogen is considered a clean fuel, its production has a negative impact on the natural environment [35]. The hydrogen required for the production of ammonia and urea is obtained through the reformation of of methane steam. In this reaction, methane and steam turn into carbon monoxide and hydrogen [8]. Every year, about 500 billion cubic meters of hydrogen is produced around the world, which is used in different industries, such as fertilizer production, oil refining, petrochemicals, fuel cells and the chemical industries [2]. Sustainability and environmental considerations require that hydrogen be produced from clean, abundant, reliable and cost-effective sources. Recent studies have shown that the promotion and acceleration of sustainable solutions for energy generation will inevitably lead to the replacement of traditional energy generation systems. Hydrogen will be an important component of this replacement [36] because about $96 \%$ of global hydrogen is produced by burning fossil fuels ( $48 \%$ natural gas, $30 \%$ oil, $18 \%$ coal). In contrast, water electrolysis accounts for only $4 \%$ of the world's total hydrogen production [8]. Renewably-powered water electrolysis can increase hydrogen production with no direct pollution [37].

\subsection{Water Electrolysis}

In the water electrolysis process, water is the reactant, and its hydrogen and oxygen are separated as a result of the application of a direct electric current [37] (Equation (3)):

$$
\mathrm{H}_{2} \mathrm{O}+\text { Direct current electricity } \rightarrow \mathrm{H}_{2}+\frac{1}{2} \mathrm{O}_{2}
$$


Water electrolysis is performed in a device called an electrolyzer. Electrolyzer cells are divided into bipolar plates, with one plate being an anode and the other a cathode. Hydrogen ions gather on the cathode and produce hydrogen gas [38]. In general, electrolyzers do not require constant maintenance because they have almost no moving parts. They are also silent and have a high degree of modularity, which make them perfectly suitable for home, industrial and commercial use [35]. There are several different systems for water electrolysis, which include Alkaline Water Electrolysis (AWE), Proton Exchange Membranes (PEMs), Alkaline anion Exchange Membranes (AEMs), and Solid Oxide water Electrolysis (SOE).

$\mathrm{Chi}$ and $\mathrm{Yu}$ [37] carried out the production of hydrogen through a low-temperature water electrolysis technology called PEM electrolysis. This method is faster, more efficient, more environmentally-friendly and better designed than other electrolysis methods. The efficiency of the PEM electrolyzer is 57-64\% LHV (Lower Heating Value) per kg of H2 [8]. Using the renewable energies available on the site, it is possible to electrolyze water and produce hydrogen without having to move the materials, which can be very efficient. In this study, the water used in the electrolysis was assumed to be agricultural water [37].

\subsection{General Scheme of On-Site Fertilizer Production in Farmlands}

The proposed scheme of fertilizer production is illustrated in Figure 4. This scheme can work with four renewable energy technologies: solar energy technology (photovoltaic), biomass technology, wind energy technology, and solar thermal technology. The electricity generated by the renewable resources is used to power the electrolyzer, air separation system, and ammonia synthesis system. The hydrogen produced by the electrolyzer and the nitrogen produced by the air separator are fed into the compressor and subsequently synthesized into ammonia through the Haber-Bosch process. The ammonia produced is combined with carbon dioxide to produce urea fertilizer. The total energy required for the synthesis of ammonia is $11.668 \mathrm{kWh} / \mathrm{kg}-\mathrm{NH} 3$ [15], which is mostly needed for the electrolysis of the water (Table 1).

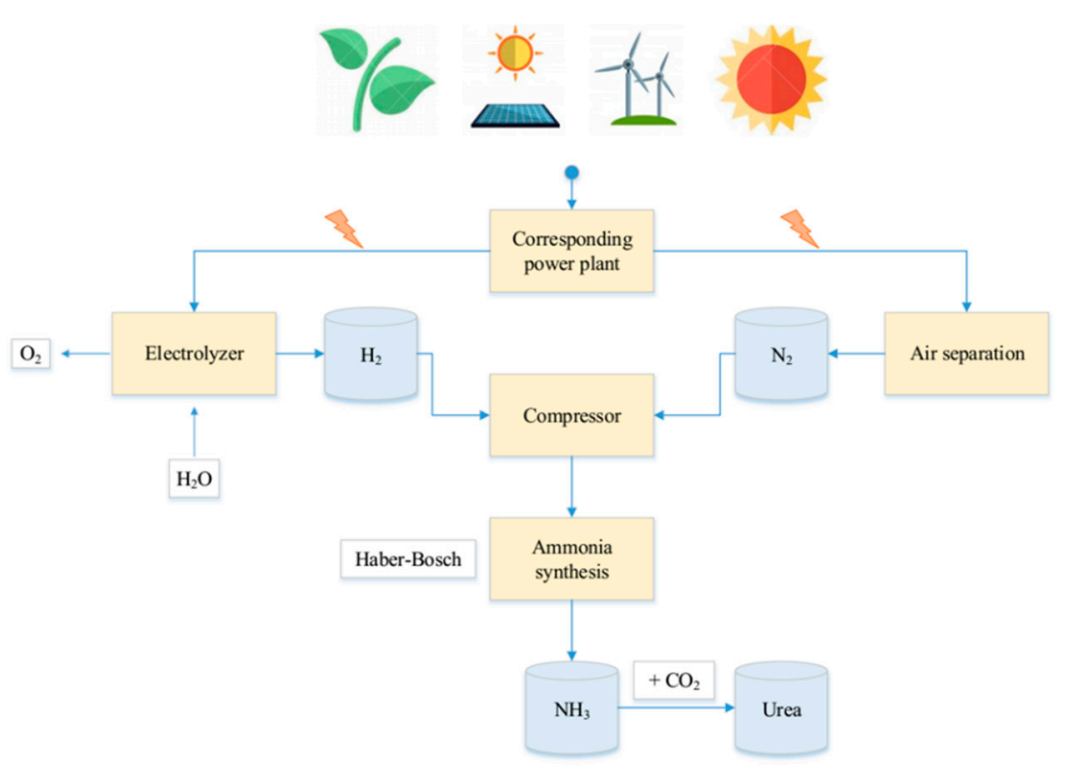

Figure 4. Proposed fertilizer production plant schematic. 
Table 1. Required energy for ammonia production.

\begin{tabular}{cc}
\hline Process & Required Energy $(\mathbf{k W h} / \mathbf{k g ~ N H})$ \\
\hline Electrolysis & 8.47 \\
Air separation & 0.098 \\
Synthesis & 3.1 \\
\hline
\end{tabular}

\section{Study Area}

Iran is located in the eastern part of the Middle East, and is bordered by the Caspian Sea to the north, and the Persian Gulf and the Gulf of Oman to the south. It covers an area of 1,648,195 $\mathrm{km}^{2}$ with a wide variety of topologies, but with a mostly semi-arid climate [39]. Iran has massive oil and natural gas reserves, which account for about $10 \%$ of the world's total crude oil reserves and $13 \%$ of OPEC (Organization of the Petroleum Exporting Countries) gas reserves [40]. In addition to fossil fuel reserves, this country has excellent potential to harvest renewable energies. It is estimated that, by 2050, the population of Iran will reach 92.2 million, and electricity consumption in this country will exceed 504.5 TWh. Therefore, given the finite nature of oil and natural gas reserves, the country should inevitably invest in different energy sources. Under the COP21 treaty (COP stands for Conference of Parties, an annual meeting of all nations that make up the United Nations Framework on Climate Change), Iran is committed to producing $7500 \mathrm{MW}$ of renewable energy by 2030. Because of the massive subsidies that the Iranian government pays to energy consumers, energy consumption in this country is highly inefficient. However, the government has recently shown more interest in promoting renewable energy in different sectors, and in stimulating a shift from fossil fuels to new energies [41]. The existence of excellent renewable energy potentials in Iran provides a good foundation for the expansion of activities related to these energies for this country. In Iran, renewable energies are mostly produced in two ways: concentrated power plants and small distributed systems [42].

\section{Materials and Methods}

\subsection{Model Description}

Multi-criteria decision-making methods (MCDMs) are widely used in the field of renewable energy management, and specifically in energy policy analysis, technology selection, project evaluation, and environmental impact analysis [43]. Troldborg et al. [44], Al garni et al. [45], and Streimikiene et al. [46] showed that MCDM models could be used to evaluate, compare and rank different renewable energy sources based on a comprehensive set of technical, environmental, economical, and social criteria. Research has shown that methods like the Analytic Hierarchy Process (AHP), which capture both quantitative and qualitative data, are particularly useful for the analysis of energy policies [47]. Since the problem of choosing the best renewable energy resource for a particular application involves a high degree of uncertainty, combining MCDMs with fuzzy theory [48], which is very efficient in dealing with uncertainties in decision-making problems [49], can provide a very effective approach for the selection and assessment of renewable energy sources. In this study, a hybrid model consisting of fuzzy AHP (to determine the weights of the criteria) and the extended TODIM (to rank the renewable energy sources) was used to determine the best renewable energy resources for the production of fertilizer in Iranian farmlands. The framework of this study is shown in Figure 5. 


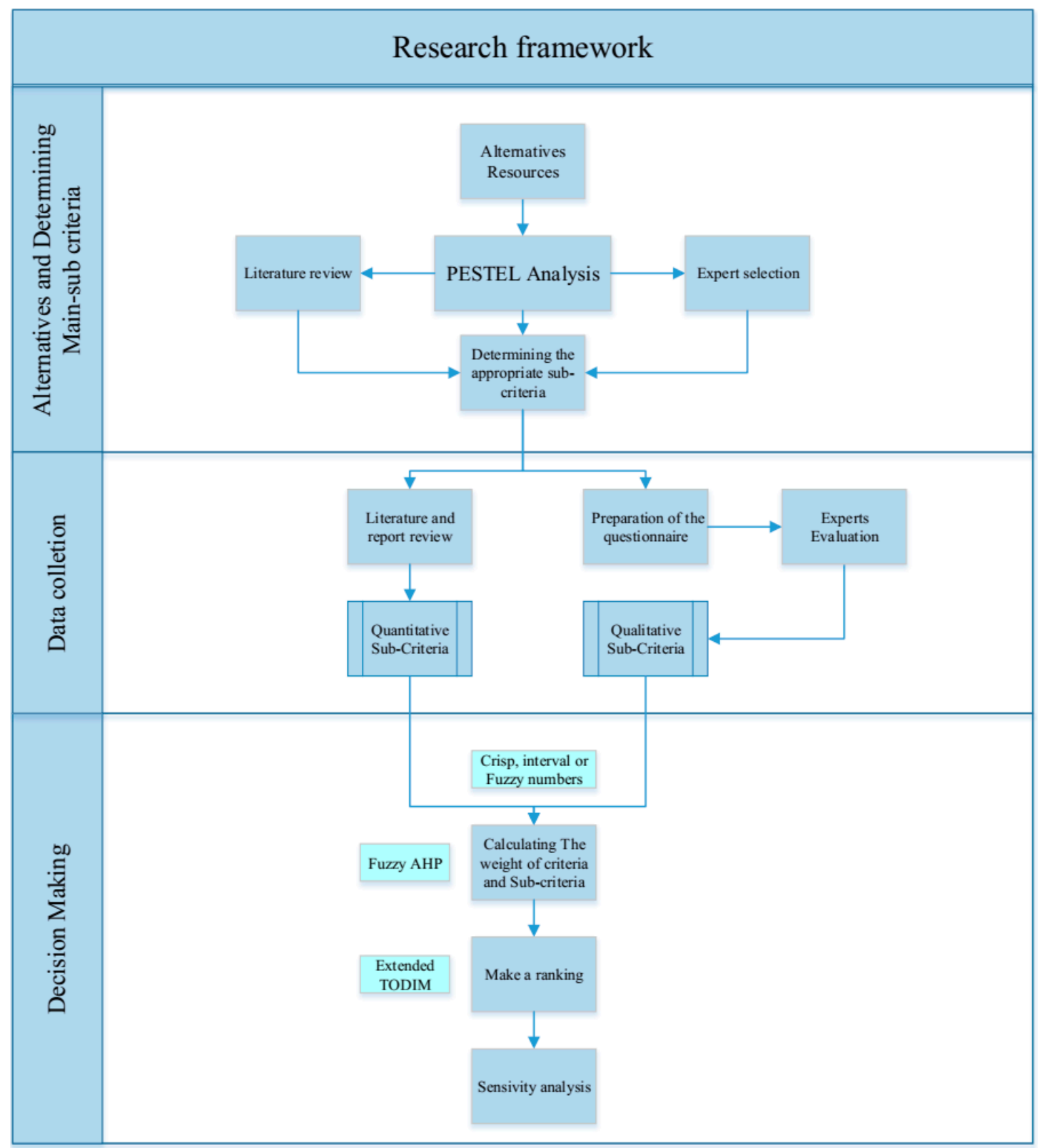

Figure 5. Research framework.

This study enlisted the help of twenty three energy experts, consisting of two experts in the field of the environment, three experts in the field of renewable energies and one expert in meteorology, from the academic, research and industrial sectors, for two purposes:

1. The choice of the suitable sub-criteria for the selection of renewable energy resources for on-site fertilizer production in Iranian farmlands. For this purpose, the experts received a questionnaire including a summary of the study and the methods used. They were then asked to select appropriate sub-criteria from the sub-criteria obtained from the literature, and the parameters that they consider important. They also evaluated options that did not have available data or could not be measured when the sub-criteria were identified. It should be noted that if the sub-criteria selected by the experts were interdependent, they were removed, because, in the AHP method, there can be no interrelation between the decision criteria (sub-criteria). 
2. Making pairwise comparisons between criteria to determine their weights by using linguistic variables. To this end, the experts received a questionnaire for pairwise comparisons and, after completing it, the paired comparisons matrix was then obtained.

\subsection{Analyzed Options}

This study considered four renewable energy-based options for the production of fertilizer in Iranian farmlands. All of these options are based on electrolysis. The electricity generated by these options can be commercialized, and has the lowest possible emission levels. It is assumed that part of the agricultural land is occupied to deploy the RER equipment. These options are described below.

\subsubsection{Solar Energy}

Solar energy is a type of renewable energy that is obtained through the absorption of solar radiation into photovoltaic cells [50]. Solar energy is the most abundant energy available to humans [51]. The amount of solar radiation received on the ground's surface depends on the season, humidity, altitude, time of day, and local weather. Solar energy can be transformed into two more useful types of energy: electricity and heat [16]. In the first case, photovoltaic cells absorb the sunlight and turn it into electricity. Photovoltaic panels can be used for both industrial-scale and domestic-scale energy production [44]. Given the availability of solar energy in all of the sites of agricultural activity, it is a major solution candidate for sustainable energy generation for fertilizer production [11]. On average, Iran has about 300 sunny days per year, and an average solar radiation of $2200 \mathrm{kWh} / \mathrm{m}^{2}$. Thus, harvesting even $1 \%$ of the country's total solar energy potential at $10 \%$ efficiency would provide about 9 million megawatts of electricity per day. It has been estimated that the real amount of annual sunlight hours in Iran is more than 2800 [40]. The photovoltaic power generation capacity of Iran by the end of 2018 was $285.35 \mathrm{MW}$ [42].

\subsubsection{Biomass Energy}

Biomass is a type of renewable energy that is extracted from organic matter. The main sources of biomass energy are wood, food, woody or herbaceous plants, agricultural and forestry residues, animal wastes, the organic fraction of urban and industrial waste, and fumes from landfills [1]. In recent decades, the rapid growth of the population and urbanization have provided easier access to biomass, especially in urban waste [45]. It has been estimated that about $10 \%$ of the world's energy needs can be met with biomass [51]. This energy source can be used directly to generate electricity or heat, or it can be converted into other energy carriers, such as biofuels and biogas [44]. Iran also has a high potential for the generation of biomass energy. It has about 133 million square meters of forests and produces large amounts of urban waste, animal waste, lignocellulosic material (the main input for bioethanol production and gasification), and algae (the most important raw material for biodiesel production) [52]. By the end of 2018, the biomass power generation capacity in Iran was 10.5 MW [42]. In this study, the electricity needed was generated by burning waste products. Various sources, such as animal manure and the agricultural residue from crops, can be used to generate electricity in the fields. Agricultural residues from crops are better at generating electricity [50].

\subsubsection{Wind Energy}

Wind energy generation is the conversion of wind into a useful form of energy using turbines. After more than two decades of the commercial and industrial use of wind energy and the maturity of wind energy technologies, the wind energy industry is still steadily growing [51]. Wind power plants can provide many economic benefits in both developed and developing countries [16]. By the end of 2018 , the world's total wind power generation capacity was $600 \mathrm{GW}$, with the largest share belonging to China (200 GW) and the United States (100 GW) [53]. In many parts of Iran, the geographic conditions and low air pressure provide good potentials for the harvesting of wind energy [41]. In a wind energy potential assessment project, the recoverable wind power potential of Iran was estimated to be about 
100 GW [42]. While many developed countries with different renewable potentials have achieved a rapid increase in the use of this renewable energy [54], Iran's wind energy capacity stagnated at 282.16 MW in 2018 [52].

\subsubsection{Solar Thermal Energy}

Solar thermal energy generation, or concentrated solar power (CSP) generation, involves using mirrors or reflectors to concentrate solar radiation onto a heat transfer medium, and then using the energy absorbed by this medium to generate electricity [45]. The solar collectors of solar thermal energy generation systems consist of two components: reflectors (mirrors), which reflect and focus the sunlight, and receivers, which absorb the focused sunlight. In most of these systems, the heat transfer fluid is pumped through the receiver to absorb the heat, which is then used to produce steam. In the turbine, this steam is turned into mechanical energy, which drives the generator to produce electricity [50]. CSP plants can generate electricity at both day and night [1]. Despite Iran's excellent solar energy potential, the country has failed to exploit this potential, and still supplies less than $1 \%$ of its total power demand from solar sources [41]. The net solar thermal potential of Iran, with the assumption of $35 \%$ efficiency for the generation system, has been estimated at 91,000 TW [55]. In 2011, the solar thermal energy generation capacity in Iran was 17 MW [41].

Despite the abundance of renewable energy resources in Iran, the exploitation of these resources requires further attention being given to the political, economic, social, technical, environmental and legal issues concerning this area.

\subsection{Criteria}

The abundant renewable energy resources available in Iran cannot be exploited without attention being given to the related political, economical, social, technical, environmental and legal issues. The use of appropriate analysis criteria and sub-criteria in the assessment of renewable energy sources is essential for informed decision-making in this area [49]. Finding suitable criteria and sub-criteria is the first step in the comparison of the available options. In this study, these criteria were determined by PESTEL analysis, as described below.

\section{PESTEL Analysis}

The method used in this study to determine the suitable criteria and sub-criteria is PESTEL analysis (Political, Economic, Socio-cultural, Technological, Environmental and Legal). The literature contains several definitions for this analysis, such as PEST [56] and STEPE [57]. Originally introduced by Aguilar in the form of ETPS (Economic, Technical, Political, and Social), this analysis was gradually modified into a model for the analysis of the effect of external and environmental factors or changes on an organization. Initially, PESTEL analysis was mostly used in corporate strategic management, but it gradually found application in other disciplines as well [58].

In this study, after reviewing the literature related to the evaluation of renewable resources, and the comments of the consulted experts based on the factors of the PESTEL analysis, a number of sub-criteria that are relevant to the subject of interest were identified in Table 2.

Table 2. Expert inputs and the review of the studies using MCDM to evaluate the renewable energy resources.

\begin{tabular}{cccc}
\hline Main D.C & NO. & Sub-Criteria & References \\
\hline & 1 & Political acceptance & {$[45,47,50]$} \\
Political & 2 & Compatibility with the national energy policy & {$[16,45,50]$} \\
& 3 & Political benefit & Expert inputs \\
& 4 & National energy security & {$[1]$} \\
& 5 & Sanction & Expert inputs \\
& 6 & Policy applicability & {$[22]$} \\
\hline
\end{tabular}


Table 2. Cont.

\begin{tabular}{|c|c|c|c|}
\hline Main D.C & NO. & Sub-Criteria & References \\
\hline \multirow{14}{*}{ Economic } & 1 & Capital Cost & {$[1,16,45-47,49,52,59,60]$} \\
\hline & 2 & Operation and maintenance $(\mathrm{OM})$ Cost & {$[1,16,45-47,49,52,59,60]$} \\
\hline & 3 & Payback time & {$[16,47,49,50]$} \\
\hline & 4 & R \& D Cost & {$[1,45]$} \\
\hline & 5 & Electricity cost & {$[1,49,51,61,62]$} \\
\hline & 6 & Costs of grid connection & [46] \\
\hline & 7 & Technology Cost & [16] \\
\hline & 8 & Energy Cost & {$[45,63]$} \\
\hline & 9 & Market maturity & {$[45,64]$} \\
\hline & 10 & Operational life & {$[45,47]$} \\
\hline & 11 & Availability of funds & [50] \\
\hline & 12 & National economic development & [45] \\
\hline & 13 & Market potential & {$[22,49,60]$} \\
\hline & 14 & Security of supply & [46] \\
\hline \multirow{8}{*}{ Social } & 1 & Job creation & {$[1,16,44-46,49,51,59]$} \\
\hline & 2 & Social benefit & {$[1,16,47,49]$} \\
\hline & 3 & Local welfare & Expert inputs \\
\hline & 4 & Accident fatalities & [46] \\
\hline & 5 & Social acceptance & {$[1,16,22,44,45,47,49-51,61,62,64]$} \\
\hline & 6 & Maintain leading position as energy supplier & [45] \\
\hline & 7 & Investors' awareness and information & Expert inputs \\
\hline & 8 & Human health & {$[10,32,45,46]$} \\
\hline \multirow{18}{*}{ Technology } & 1 & Safety of energy system & {$[45,47]$} \\
\hline & 2 & Safety in covering peak demand & {$[45,46]$} \\
\hline & 3 & Stability & [59] \\
\hline & 4 & Efficiency & {$[1,16,22,45,49-51,61,64]$} \\
\hline & 5 & Reliability & {$[1,16,22,44,45,47,49,50,59,60,62]$} \\
\hline & 6 & Resource availability & {$[1,16,45,49]$} \\
\hline & 7 & Risk & [50] \\
\hline & 8 & Technical maturity & {$[1,16,22,44,45,47,49-51,61,64]$} \\
\hline & 9 & Feasibility & {$[50,63]$} \\
\hline & 10 & Capacity & {$[16,47,50,51,61,62]$} \\
\hline & 11 & Load factor & [46] \\
\hline & 12 & Deployment time & {$[1,45,63]$} \\
\hline & 13 & Durability of technology & {$[62]$} \\
\hline & 14 & Expert human resource & {$[1,45]$} \\
\hline & 15 & Future installed capacity & [61] \\
\hline & 16 & Ease of decentralization & [45] \\
\hline & 17 & Ease of running on farmland & Expert inputs \\
\hline & 18 & Electricity generation & {$[44,61]$} \\
\hline \multirow{11}{*}{ Environmental } & 1 & Land requirement & {$[1,16,44,45,49-51,65]$} \\
\hline & 2 & Emission reduction & {$[1,44-47,50,51,60,65]$} \\
\hline & 3 & Impact on environment & {$[16,45,47,49,50,59]$} \\
\hline & 4 & Need for waste disposal & {$[45,47]$} \\
\hline & 5 & Disturbance ofecological balance & [45] \\
\hline & 6 & Climate change & {$[10,62]$} \\
\hline & 7 & Pollution emission & {$[16,61,62]$} \\
\hline & 8 & Impact on amenity & [44] \\
\hline & 9 & Global warming & {$[22,30]$} \\
\hline & 10 & Human toxicity & {$[10,22,30]$} \\
\hline & 11 & Ecosystem quality & [10] \\
\hline \multirow{3}{*}{ Legal } & 1 & Legal regulation of activities & [62] \\
\hline & 2 & Governmental support & [61] \\
\hline & 3 & Legal incentives & [16] \\
\hline
\end{tabular}


After the PESTEL analysis, 23 sub-criteria were determined by the experts, and three sub-criteria were omitted due to their interdependence with the opinion of the experts. Finally, 20 sub-criteria for the ranking of renewable resources for on-site fertilizer production in farmlands in Iran were identified. Quantitative data were gathered from various sources, including country databases and literature, and qualitative data were obtained from expert opinions in Table 3.

Table 3. The selected decision sub-criteria, with their data references.

\begin{tabular}{|c|c|c|c|c|c|}
\hline Main Criteria & NO. & Sub-Criteria & Unit & Type & Data Reference \\
\hline \multirow{3}{*}{ Political } & 1 & Political acceptance & Qualitative (1-5) & Positive & Experts inputs \\
\hline & 2 & Political benefit & Qualitative (1-5) & Positive & Experts inputs \\
\hline & 3 & Sanction & Qualitative (1-5) & Negative & Ministry of Energy of Iran [42] \\
\hline \multirow{3}{*}{ Economic } & 1 & Capital Cost & $\mathrm{USD} / \mathrm{kW}$ & Negative & {$[1,41,45,49,66-68]$} \\
\hline & 2 & Operation and maintenance (OM) Cost & $\mathrm{USD} / \mathrm{kW} / \mathrm{y}$ & Negative & {$[1,49,51,67]$} \\
\hline & 1 & Local welfare & Qualitative (1-5) & Positive & Experts inputs \\
\hline \multirow[t]{5}{*}{ Social } & 2 & Social acceptance & Qualitative (1-5) & Positive & Experts inputs \\
\hline & 3 & Investors' awareness and information & Qualitative (1-5) & Positive & Experts inputs \\
\hline & 1 & Safety of energy system & Qualitative (1-5) & Positive & Experts inputs \\
\hline & 2 & Efficiency & $\%$ & Positive & {$[22,45,51,67]$} \\
\hline & 3 & Reliability & Qualitative (1-5) & Positive & {$[44,47,63]$, Experts inputs } \\
\hline \multirow{5}{*}{ Technological } & 4 & Technical maturity & Qualitative (1-5) & Positive & {$[45,49]$, Experts inputs } \\
\hline & 5 & Feasibility & Qualitative (1-5) & Positive & {$[50,63]$, Experts inputs } \\
\hline & 6 & Capacity & $\%$ & Positive & [68] \\
\hline & 7 & Resource availability & $\mathrm{kWh} / \mathrm{m}^{2} / \mathrm{y}$ & Positive & {$[45,49]$} \\
\hline & 8 & Ease of running on farmland & Qualitative (1-5) & Positive & Experts inputs \\
\hline \multirow{2}{*}{ Environmental } & 1 & Emission reduction & $\mathrm{g} \mathrm{CO}_{2} \mathrm{eq} / \mathrm{kWh}$ & Negative & {$[44,45]$} \\
\hline & 2 & Human toxicity & g 1,4-DBeq/ kWh & Negative & {$[68]$} \\
\hline \multirow{2}{*}{ Legal } & 1 & Legal regulation of activities & Qualitative (1-5) & Negative & Experts inputs \\
\hline & 2 & Legal incentives & Qualitative (1-5) & Positive & Experts inputs \\
\hline
\end{tabular}

\section{C1. Political Criteria}

The sub-criteria identified for this criterion are as follows:

C1.1. Political Acceptance: This sub-criterion represents the level of satisfaction of policymakers and authorities with renewable energy technologies, and how accepted are these technologies among these groups. This acceptance can affect the length of the projects and the support they receive, including logistic support, from the political domain. In the evaluation based on this sub-criterion, an option is considered suitable if the related technology is consistent with national policies.

C1.2. Political Benefit: This sub-criterion evaluates the political benefits of a resource, such as its contribution to national energy security and political uses, etc.

C1.3. Sanction: This sub-criterion considers the impact of sanctions on renewable energy sources. With the imposition of sanctions, some foreign companies may choose to avoid doing business with domestic entities, which may make it more difficult to access the equipment and facilities needed to build and maintain renewable power plants. Therefore, those options whose components are being produced domestically are preferable.

\section{C.2. Economic Criteria}

Economic considerations play a crucial role in the assessment of renewable energy resources, especially considering that the cost of energy is the main cause of the survival of renewable technologies in the market [46]. In this dimension, four sub-criteria were considered:

C2.1. Capital Cost: This cost is the most typically considered economic factor in renewable energy assessments. In this study, the capital cost considered for the on-site production of chemical fertilizer (NH3) in farmlands was the cost of building a plant (including the purchase of technical equipment and technologies), road construction costs, installation costs, land-related costs, building-related costs, and the costs of engineering services.

C2.2. Operation and Maintenance (OM) cost: This cost consists of two components: (a) operating costs, which include wages and the cost of the goods and services needed for the operation; (b) maintenance 
costs, which refer to the costs incurred to maintain and repair the system, with the goal of increasing its lifespan and avoiding obstacles to the project's success.

\section{C3. Social Criteria}

The cub-criteria considered for the social dimension are as follows:

C3.1. Local welfare: This represents the contribution of the energy system to the improvement of local welfare, which can manifest as improved quality of life and increased local incomes.

C3.2. Social acceptance: This sub-criterion represents the public acceptance of the energy system in the society.

C3.3. Investors' awareness and knowledge: The more informed the investors are about renewable energy technology and its possible uses in agriculture, the more desirable that option will be.

\section{C4. Technical Criteria}

The sub-criteria of this criterion are as follows:

C4.1. Safety of the Energy System: This reflects the safety of workers and the rate of fatal accidents in the process of building, launching and operating a particular renewable energy system. In this sub-criterion, the rate of non-fatal accidents is expressed qualitatively [45].

C4.2. Efficiency: This refers to the useful energy obtained from the resources. This variable is usually expressed by the efficiency coefficient, which is the ratio of output energy to input energy.

C4.3. Reliability: This is determined by the frequency of the interruptions in the operation of the renewable energy resource, and reflects its stability and predictability.

C4.4. Technical Maturity: This sub-criterion refers to the advancement of the renewable energy technology, and whether it can be practically used at regional, national, and international levels.

C4.5. Feasibility: This indicates the ease of the implementation of the renewable energy system. This sub-criterion can be estimated based on the number of times the option has been successful in the tests.

C4.6. Capacity: This is the amount of electrical energy that the renewable energy resource will produce over a given period of time, divided by the maximum amount of energy that a renewable plant can produce.

C4.7. Resource Availability: This sub-criterion represents the availability of the renewable energy. Naturally, an option with higher availability is more desirable (e.g., the availability of good sunlight, good wind speed, large amounts of organic waste, etc.).

C4.8. Ease of Implementation in farmlands: The ease of the construction and operation of the system is of essential importance for the launching of a renewably-powered fertilizer production system in a farmstead. Therefore, the easier it is to build and operate a renewable system, the better that option will be.

\section{C5. Environmental Criteria}

This criterion has the following sub-criteria:

C5.1. Emission Reduction: Energy generation facilities usually contribute to pollution not only directly but also indirectly through the carbon footprint of the related construction, transportation, operation, maintenance and demolition activities. Therefore, the options with lower total emissions are more desirable. This sub-criterion is measured in terms of the equivalent emissions of $\mathrm{CO} 2$ as the metric of its contribution to global warming, air pollution, and acid rain [16].

C5.2. Human Toxicity: This sub-criterion concerns the release of toxic substances into the human environment. However, it does not cover the health risks of workplaces. The factors of human toxicity potential are determined by USELCA (The Uniform System for Evaluation of Substances). It is typical 
to use 1, 4-dichlorobenzene equivalents per kg of emissions as the metric of the human toxicity of substances [17].

\section{C6. Legal Criteria}

The sub-criteria of this group are as follows:

C6.1. Legal Regulation of Activities: This sub-criterion considers the legal provisions and government support concerning renewable energy activities. The lower the legal barriers to using the renewable energy resource, the better the option.

C6.2. Legal Incentives: This sub-criterion refers to the impact of energy policies and legal incentives regarding the use of renewable energies for the production of fertilizer on the decisions of farmers and investors.

\subsection{Fuzzy AHP}

The combinations of modified AHP methods and other multi-criteria methods have extensive use in energy studies [69]. The AHP method is widely used for MCDM in various fields including energy [43].

Due to the availability and uncertainty of information and the vagueness of human recognition, it is relatively difficult to provide exact numerical values for the criteria. The combination of MCDM methods and fuzzy set theory has been applied in many systems, such as energy systems [69].

The fuzzy AHP method presented by Chang [70] has the following steps [69]:

Step 1: The matrix of pairwise comparison is defined as follows:

$$
\widetilde{Z}=\left(Z_{i j}\right) n * n\left[\begin{array}{ccc}
(1,1,1) & \left(p_{12}, q_{12}, r_{12}\right) & \left(p_{1 n}, q_{1 n}, r_{1 n}\right) \\
\left(p_{21}, q_{21}, r_{21}\right) & (1,1,1) & \left(p_{2 n}, q_{2 n}, r_{2 n}\right) \\
\left(p_{n 1}, q_{n 1}, r_{n 1}\right) & \left(p_{n 2}, q_{n 2}, r_{n 2}\right) & (1,1,1)
\end{array}\right]
$$

where we have: $z_{i j}=\left(p_{i j}, q_{i j}, r_{i j}\right)$.

$X=\left\{x_{1}, x_{2}, x_{3}, \ldots, x_{n}\right\}$ is considered to be the object set, and $T=\left\{t_{1}, t_{2}, t_{3}, \ldots, t_{m}\right\}$ is the goal set. $M_{g_{i}}^{1}, M_{g_{i}}^{2}, \ldots, M_{g^{\prime}}^{m}, i=1,2, \ldots, n$ where all $M_{g_{i}}^{j}(j=1,2, \ldots, m)$ are triangular fuzzy numbers.

Step 2: The value of the fuzzy value is defined according to the i-th object, as follows:

$$
S_{i}=\sum_{j=1}^{m} M_{g_{i}}^{j} *\left[\sum_{i=1}^{n} \sum_{j=1}^{m} M_{g_{i}}^{j}\right]^{-1}
$$

where $\sum_{j=1}^{m} M_{g_{i}}^{j}$ is obtained by:

$$
\sum_{j=1}^{m} M_{g_{i}}^{j}=\left(\sum_{j=1}^{m} p_{j}, \sum_{j=1}^{m} q_{j}, \sum_{j=1}^{m} r_{j}\right)
$$

To calculate $\left[\sum_{i=1}^{n} \sum_{j=1}^{m} M_{g_{i}}^{j}\right]^{-1}$, the $\left[\sum_{i=1}^{n} \sum_{j=1}^{m} M_{g_{i}}^{j}\right]$ is calculated first.

$$
\sum_{i=1}^{n} \sum_{j=1}^{m} M_{g_{i}}^{j}=\left(\sum_{i=1}^{n} p_{i}, \sum_{i=1}^{n} q_{i}, \sum_{i=1}^{n} r_{i}\right)
$$


The inverse of Equation (7) is expressed by:

$$
\left[\sum_{i=1}^{n} \sum_{j=1}^{m} M_{g_{i}}^{j}\right]^{-1}=\left(\frac{1}{\sum_{i=1}^{n} r_{i}}, \frac{1}{\sum_{i=1}^{n} q_{i}}, \frac{1}{\sum_{i=1}^{n} p_{i}}\right)
$$

Step 3: With the fuzzy synthetic extent, the degree of probability $M_{2}\left(p_{2}, q_{2}, r_{2}\right) \geq M_{1}\left(p_{1}, q_{1}, r_{1}\right)$ is defined as:

$$
\begin{aligned}
& V\left(M_{2} \geq M_{1}\right)=h g t\left(M_{1} \cap M_{2}\right)=\mu_{M_{2}}(d) \\
& \quad=\left\{\begin{array}{cl}
1 & \text { if } q_{2} \geq q_{1} \\
0 & \text { if } p_{2} \geq r_{2} \\
\frac{p_{1}-r_{2}}{\left(q_{2}-r_{2}\right)-\left(q_{1}-p_{1}\right)} & \text { otherwise }
\end{array}\right.
\end{aligned}
$$

where $\mathrm{d}$ is the ordinate of the highest intersection point between $\mu_{M_{1}}$ and $\mu_{M_{2}}$.

Step 4: The probability degree for a convex fuzzy point (e.g., $\left.M_{i}(i=1,2, \ldots, k)\right)$ is greater than the $\mathrm{k}$ concave fuzzy point which is as defined as follows:

$$
\begin{aligned}
& V\left(M \geq M_{1}, M_{2}, \ldots, M_{k}\right) \\
& =V\left[\left(M \geq M_{1}\right),\left(M \geq M_{2}\right), \ldots, \text { and }\left(M \geq M_{k}\right)\right] \\
& =\min V\left(M \geq M_{i}\right), i=1,2,3, \ldots, k .
\end{aligned}
$$

If we assume the following for $k \neq i$ and $k=1,2, \ldots, n$ :

$$
d^{\prime}\left(A_{i}\right)=\min V\left(S_{i} \geq S_{k}\right)
$$

then the weight vector is derived the following equation:

$$
W=\left(d^{\prime}\left(A_{1}\right), d^{\prime}\left(A_{1}\right), \ldots, d^{\prime}\left(A_{n}\right)\right)^{T}
$$

where $A_{i}(i=1,2, \ldots, n)$ are $n$ elements.

Step 5: The normalized weight vectors can be obtained after normalization expressed by:

$$
W=\left(d\left(A_{1}\right), d\left(A_{1}\right), \ldots, d\left(A_{n}\right)\right)^{T}
$$

where $W$ is a non-fuzzy number. The present research used the fuzzy AHP method to calculate the weight of all of the sub-criteria.

\subsection{MCDM Method}

Due to the use of MCDM techniques to solve energy decision-making problems in countries such as Iran, Spain, Greece, China, and India, and because of the importance of energy for sustainable development, countries are willing to use analytical methods to determine energy policies. Therefore, conventional and fuzzy MCDM methods are used to address energy-based decision-making problems in different regions of the world [50].

The MCDM method used in this article is the Extended TODIM method described below.

\subsubsection{Extended TODIM}

In 2013, Fan et al. [71] presented the extended TODIM method for multi-attribute decision-making problems. In this method, the numbers and the values of the criteria can be used in three formats (crisp numbers, fuzzy numbers, and interval numbers).

The steps of the extended TODIM method are as follows [71]:

Step 1: Transformation of three formats of criteria values. 
The three formats of the values of the criteria (crisp numbers, interval numbers, and fuzzy numbers) are transformed into the random variables format with the cumulative distribution function. The process of the transformation of each format is described below:

- The crisp number: if $x_{i j}$ is a crisp number $x_{i j}=x^{\prime}$, its cumulative distribution function is:

$$
F_{i j}(x)=\left\{\begin{array}{ll}
0, & x<x^{\prime}{ }_{i j,} \\
1, & x \geq x^{\prime}{ }_{i j},
\end{array} \quad i \in M, j \in N^{K} .\right.
$$

- Interval number: if $x_{i j}$ is an interval number and $x_{i j}=\bar{x}_{i j}=\left[x_{i j}{ }^{l}, x_{i j}{ }^{u}\right]$ is an arbitrary value in the interval $\left[x_{i j}{ }^{l}, x_{i j}{ }^{u}\right]$, its cumulative distribution function is:

$$
F_{i j}(x)=\left\{\begin{aligned}
0, & x<x_{i j}^{l}, \\
\frac{x-x_{i j}^{l}}{x_{i j}^{u}-x_{i j}^{l},} & x_{i j}^{l} \leq x<x_{i j}^{u} \quad i \in M, j \in N^{I} \\
1, & x \geq x_{i j}^{u},
\end{aligned}\right.
$$

- Fuzzy number: if $x_{i j}$ is a triangular fuzzy number, $x_{i j}=\widetilde{x}_{i j}=\left(p_{i j}, q_{i j}, r_{i j}\right)$ is then considered to be a unique random variable, and its cumulative distribution function is:

$$
F_{i j}(x)= \begin{cases}0, & x<p_{i j} \\ \frac{\left(X-p_{i j}\right)^{2}}{\left(q_{i j}-p_{i j}\right)\left(r_{i j}-p_{i j}\right)}, & p_{i j} \leq x<q_{i j} \\ \frac{-x^{2}+2 r_{i j} x-p_{i j} r_{i j}+p_{i j} q_{i j}-q_{i j} r_{i j}}{\left(r_{i j}-q_{i j}\right)\left(r_{i j}-p_{i j}\right)}, & q_{i j} \leq x<r_{i j} \\ 1, & x \geq r_{i j},\end{cases}
$$

Step 2: Calculating gains and losses.

In order to calculate the gain and loss related to each of the options, the calculation formulae for inferior and superior values are presented for the comparison of the two cumulative distribution functions.

If $x_{k j}$ and $x_{i j}$ are the values of the options $A_{i}$ and $A_{k}$ concerning criterion $\mathrm{C}_{\mathrm{j}}$, respectively, $(i, k \in M, j \in N)$, and $F_{i j}(x)$ and $F_{k j}$ are the cumulative distribution functions $x_{i j}$ and $x_{i j}$, respectively, and the superior and inferior values of $F_{i j}(x)$ relative to $F_{k j}$ are expressed by:

$$
\begin{aligned}
& D\left(F_{i j}(x), F_{k j}(x)\right)=\int_{\Omega_{i k}^{j}}\left[F_{k j}(x)-F_{i j}(x)\right] d x, i, k \in M, j \in N_{b} \\
& T\left(F_{i j}(x), F_{k j}(x)\right)=\int_{\theta_{i k}^{j}}\left[F_{i j}(x)-F_{k j}(x)\right] d x, i, k \in M, j \in N_{b}
\end{aligned}
$$

where $\Omega_{i k}^{j}=\left\{x \mid F_{i j}(x)<F_{k j}(x), x \in\left[a_{i k^{\prime}}^{j^{*}}, b_{i k}^{j^{*}}\right]\right\}, \theta_{i k}^{j}=\left\{x \mid F_{i j}(x)>F_{k j}(x), x \in\left[a_{i k^{\prime}}^{j^{*}} b_{i k}^{j^{*}}\right]\right\}$ and $a_{i k}^{j^{*}}=\min \left\{a_{i j}, a_{k j}\right\}$ and $b_{i k}^{j^{*}}=\max \left\{b_{i j}, b_{k j}\right\}$.

- $\quad$ For crisp numbers, we have: $a_{i j}=b_{i j}=x^{\prime}{ }_{i j}, a_{k j}=b_{k j}=x^{\prime}{ }_{k j}$

- $\quad$ For interval numbers, we have: $a_{i j}=x_{i j^{\prime}}^{l}, b_{i j}=x_{i j}^{u}, a_{k j}=x_{k j}^{l}, b_{k j}=x_{k j}^{u}$

- $\quad$ For fuzzy numbers, we have: $a_{i j}=p_{i j}, b_{i j}=r_{i j}, a_{k j}=p_{k j}, b_{k j}=r_{k j}$

In the same way, for the cost criterion, the superior and inferior values $F_{i j}(x)$ relative to $F_{k j}$ are expressed by:

$$
D\left(F_{i j}(x), F_{k j}(x)\right)=\int_{\theta_{i k}^{j}}\left[F_{i j}(x)-F_{k j}(x)\right] d x, i, k \in M, j \in N_{c}
$$




$$
D\left(F_{i j}(x), F_{k j}(x)\right)=\int_{\theta_{i k}^{j}}\left[F_{i j}(x)-F_{k j}(x)\right] d x, i, k \in M, j \in N_{c}
$$

The gain of option $A_{i}$ to option $A_{k}$, considering the criterion $C j$, indicated by $G_{i k}^{j}$, is expressed by:

$$
G_{i k}^{j}=D\left(F_{i j}(x), F_{k j}(x)\right), i, k \in M, j \in N .
$$

In the same way, the loss of $A_{i}$ relative to option $A_{k}$, shown with $\mathrm{L}_{\mathrm{ik}}$, is expressed by:

$$
L_{i k}^{j}=-T\left(F_{i j}(x), F_{k j}(x)\right), i, k \in M, j \in N \text {. And we have } G_{i k}^{j} \geq 0 \text { and } L_{i k}^{j} \leq 0 .
$$

Step 3: Normalizing the profit and loss matrix.

Since gains or losses associated with different criteria are generally incommensurate, they must be normalized so as to transform them into comparable values. This is obtained by normalizing the element $G_{i k}^{j}$ and $L_{i k}^{j}$.

$$
\begin{gathered}
Y_{i k}^{j}=\frac{G_{i k}^{j}-G_{j}^{\min }}{G_{j}^{\max }-G_{j}^{\min }}, i, k \in M, j \in N, \\
Z_{i k}^{j}=\frac{L_{i k}^{j}-L_{j}^{\min }}{L_{j}^{\max }-L_{j}^{\min }}, i, k \in M, j \in N .
\end{gathered}
$$

Step 4: Calculating the degree of loss and profit dominance.

For continuous values, the gain and loss of each option $A_{i}$ over option $A_{k}, G_{i k}^{j}$ and $L_{i k}$ may exist simultaneously; therefore, the dominance degree for the gain and loss should first be calculated respectively, and then aggregated. The dominance degree for gain, $\Phi_{i k}^{j(+)}$ is given by:

$$
\Phi_{i k}^{j(+)}=\sqrt{\frac{w_{j} Y_{i k}^{j}}{w_{r} \sum_{j=1}^{n}\left(w_{j} / w_{r}\right)}}, i, k \in M, j \in N .
$$

The dominance degree for loss, $\Phi_{i k}^{j(-)}$, is given by:

$$
\Phi_{i k}^{j(-)}=-\frac{1}{\theta} \sqrt{\frac{-Z_{i k}^{j} w_{r}}{w_{j}} \sum_{j=1}^{n}\left(w_{j} / w_{r}\right)}, i, k \in M, j \in N
$$

where $w_{r}=\max \left\{w_{j} \mid j \in N\right\}$, and $\theta$ is the attenuation factor of the loss. $\theta$ represents the degree of the loss aversion of the decision-making, and $0<\theta$.

Obviously, $0 \leq^{(+)}<1$ and $\Phi^{(-)}{ }_{i k} \leq 0$.

Step 5: Calculating the dominance degree.

The dominance degree of $\Phi_{i k}^{j(+)}$ and $\Phi_{i k}^{j(-)}$ are aggregated as following:

$$
\Phi_{i k}^{j}=\Phi_{i k}^{j(+)}+\Phi_{i k}^{j(-)}, i, k \in M, j \in N .
$$

Thus, the dominance degree matrix with respect to the criterion $C j$ and $\Phi_{j}$ can be constructed as follows:

$$
\Phi_{i k}^{j}=\left[\Phi_{i k}^{j}\right]_{m \times m}=\begin{gathered}
A_{1} \\
A_{2} \\
\vdots \\
A_{m}
\end{gathered}\left(\begin{array}{cccc}
\Phi_{11}^{j} & \Phi_{12}^{j} & \cdots & \Phi_{1 m}^{j} \\
\Phi_{21}^{j} & \Phi_{22}^{j} & \cdots & \Phi_{2 m}^{j} \\
\vdots & \vdots & \cdots & \vdots \\
\Phi_{m 1}^{j} & \Phi_{m 2}^{j} & \cdots & \Phi_{m m}^{j}
\end{array}\right), j \in N
$$


where $\Phi_{i i}^{j}=0, \forall i \in M, j \in N$

Step 6: Calculating the Dominance Degree Matrix.

In the following, based on the matrix $\Phi_{j}$, the overall dominance degree matrix $\Delta$ is developed:

$$
\Delta=\left[\delta_{i k}\right]_{m \times m}=\begin{gathered}
A_{1} \\
A_{2} \\
\vdots \\
A_{m}
\end{gathered}\left(\begin{array}{cccc}
\delta_{11} & \delta_{12} & \cdots & \delta_{1 m} \\
\delta_{21} & \delta_{22} & \cdots & \delta_{2 m} \\
\vdots & \vdots & \cdots & \vdots \\
\delta_{m 1} & \delta_{m 2} & \cdots & \delta_{m m}
\end{array}\right),
$$

where $\delta_{i k}$ is the overall dominance degree of the option $A_{i}$ over option $A_{k}$.

$$
\delta_{i k}=\sum_{j=1}^{n} \Phi_{i k^{\prime}}^{j} i, k \in M
$$

Step 7: Final ranking of options.

Based on the matrix $\Delta$, the overall value of option $A_{i}, \xi\left(A_{i}\right)$ can be calculated as follows:

$$
\xi\left(A_{i}\right)=\frac{\sum_{k=1}^{m} \delta_{i k}-\min _{i \in M}\left\{\sum_{k=1}^{m} \delta_{i k}\right\}}{\max _{i \in M}\left\{\sum_{k=1}^{m} \delta_{i k}\right\}-\min _{i \in M}\left\{\sum_{k=1}^{m} \delta_{i k}\right\}}, i \in M .
$$

Obviously, $0 \leq \xi\left(A_{i}\right) \leq 1$ and the greatest $\xi\left(A_{i}\right)$ is the best option $A_{i}$. Therefore, by descending order of final value for the alternatives, all alternatives can be ranked, and the desirable alternative can be selected.

The variables that can be expressed in linguistic terms are called linguistic variables [69]. The linguistic variables used for the fuzzy AHP and Extended TODIM processes are illustrated

\begin{tabular}{|c|c|c|c|}
\hline \multirow{2}{*}{ Linguistic Nariable } & \multicolumn{2}{|c|}{ Fuzzy Number for F-AHP } & \multirow{2}{*}{$\begin{array}{l}\text { Fuzzy Number for } \\
\text { Extended TODIM }\end{array}$} \\
\hline & $i$ to $j$ Response & Inverse of Fuzzy Number ( $j$ to $i$ ) & \\
\hline Very Low (VL) & $(1,1,1)$ & $(1,1,1)$ & $(0,0,0.25)$ \\
\hline Low $(\mathrm{L})$ & $(1,1,3)$ & $(1 / 3,1,1)$ & $(0,0.25,0.5)$ \\
\hline Medium (M) & $(1,3,5)$ & $(1 / 5,1 / 3,1)$ & $(0.25,0.5,0.75)$ \\
\hline $\operatorname{High}(\mathrm{H})$ & $(3,5,7)$ & $(1 / 7,1 / 5,1 / 3)$ & $(0.5,0.75,1)$ \\
\hline Very High (VH) & $(5,7,9)$ & $(1 / 9,1 / 7,1 / 5)$ & $(0.75,1,1)$ \\
\hline
\end{tabular}
in Table 4.

Table 4. Linguistic variables used for the fuzzy AHP and Extended TODIM process [69].

As shown in Figure 6, the hierarchy diagram of this study consists of four levels (objective, criteria, sub-criteria, and options) with six criteria, 20 sub-criteria, and four options. 


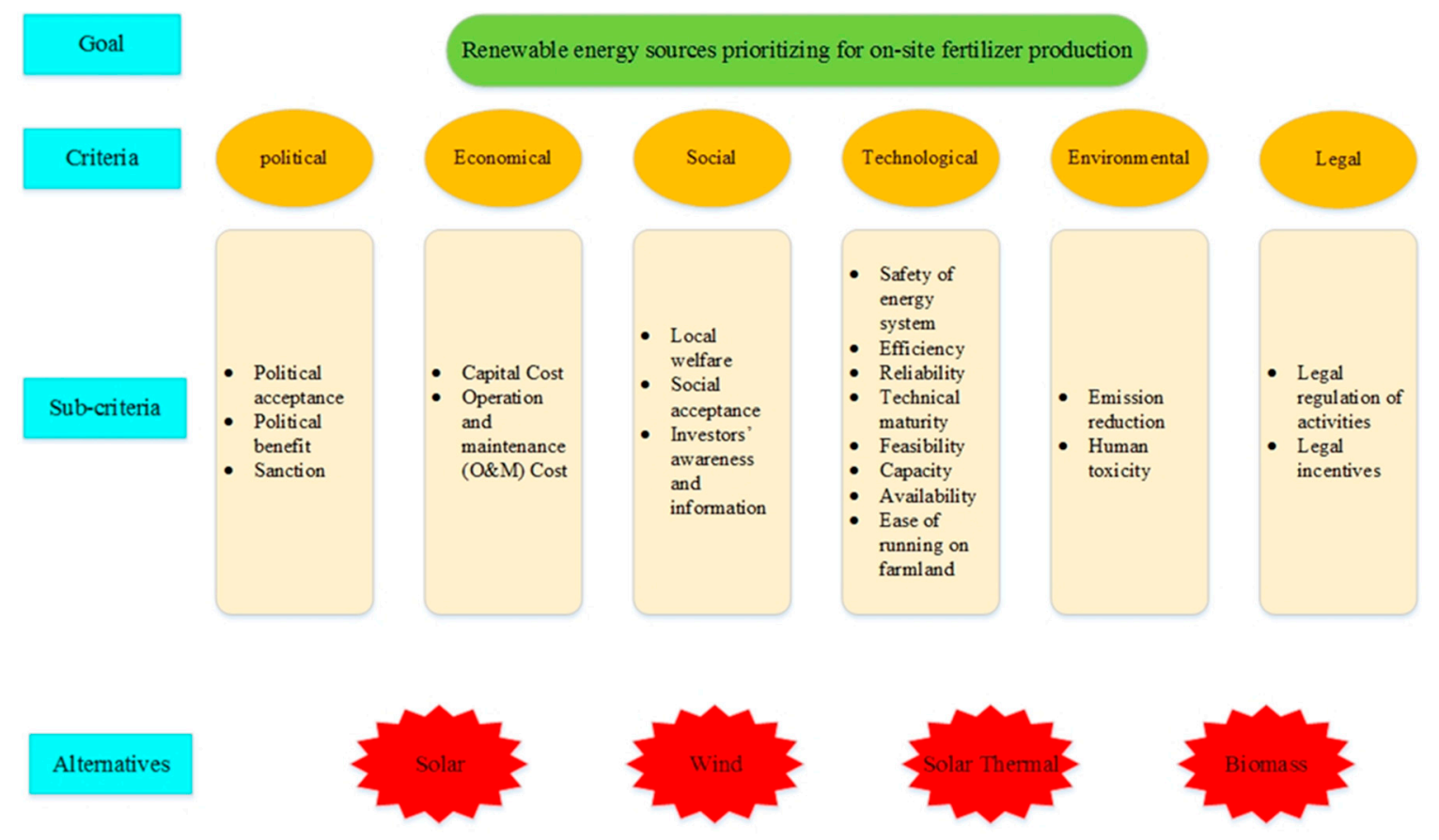

Figure 6. Analytical hierarchy process diagram.

\section{Results}

\subsection{Weight Determination}

The six respondents from the universities and industry were asked to fill in the questionnaire of the pairwise comparison matrix among six criteria (the pairwise matrix is attached as Table A1). The respondents were asked to express their relative judgment of one element versus another by Linguistic variables.

The weights of the criteria, which were calculated by the Fuzzy AHP method, are listed in Table 5. According to the experts' opinions, the technological criterion was found to be the most important criterion for the ranking of the renewable energy resources for ammonia production in Iranian farmlands (48.88\%), followed by the economical (12.87\%), social (11\%), legal (10.03\%), environmental $(9.7 \%)$, and political $(7.52 \%)$ criteria, in descending order. In addition, as seen in Figure 7 , the most important sub-criterion is resource availability, followed by efficiency, human toxicity, reliability, local welfare, feasibility, legal regulation of activities, capital cost, capacity, OM cost, the safety of energy system, sanction, legal incentives, political benefit, political acceptance, investors' awareness, technical maturity, social acceptance, the ease of running it on farmland, and emission reduction.

Table 5. Criteria weights.

\begin{tabular}{cc}
\hline Criteria & Weigh \\
\hline Political & 0.0752 \\
Economical & 0.1287 \\
Social & 0.1100 \\
Technological & 0.4888 \\
Environmental & 0.0970 \\
Legal & 0.1003 \\
\hline
\end{tabular}




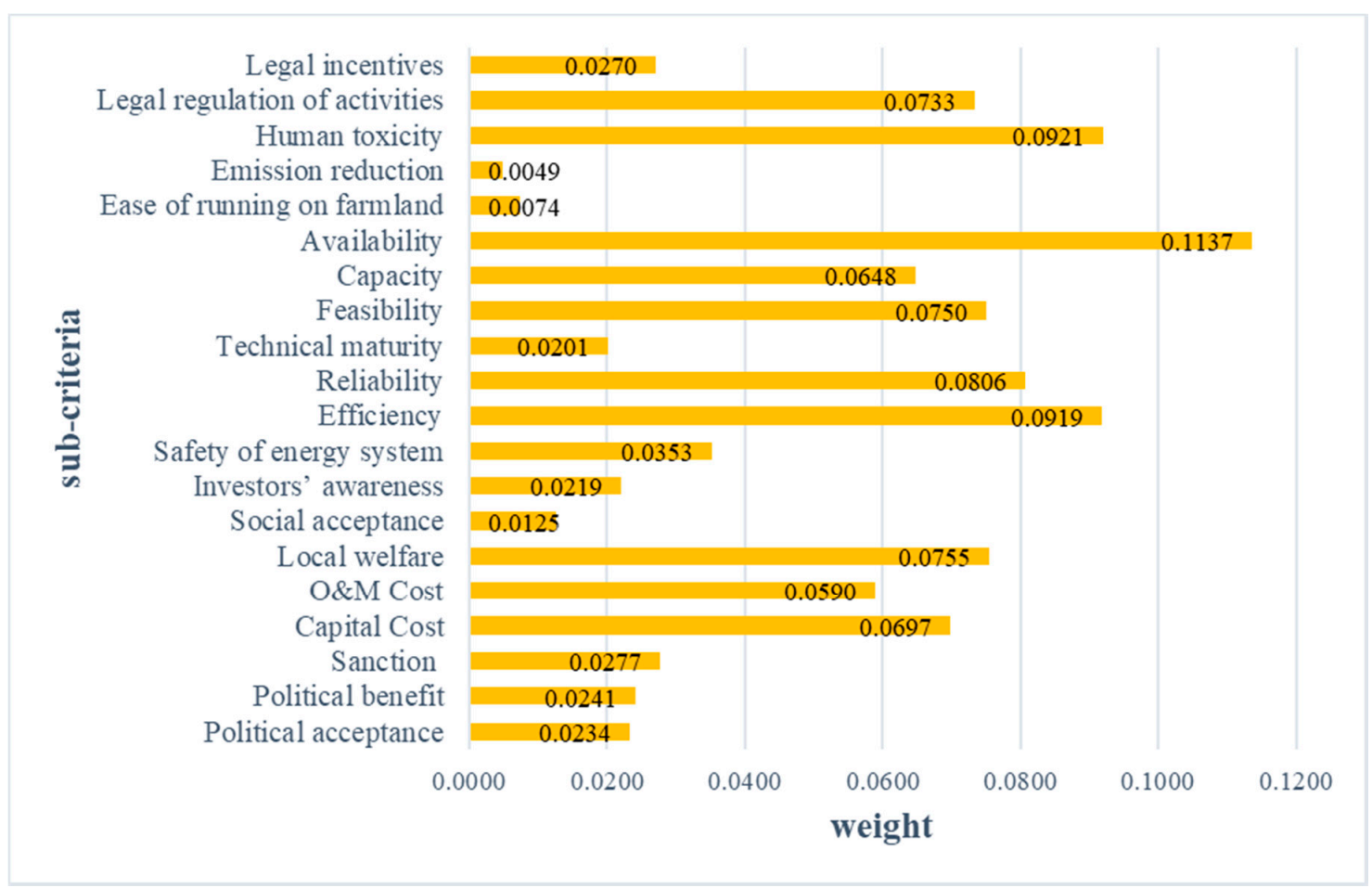

Figure 7. Sub-criteria weights.

\subsection{Results of the Extended TODIM}

In this study, we examined the most appropriate technology for the generation of electricity for agricultural farms. The prioritization system of this study includes both qualitative and quantitative sub-criteria. The estimates for this study are not simple and inherently associated with uncertainties. The qualitative sub-criteria data was obtained by gathering experts' opinions. The quantitative sub-criteria data was obtained from literature and reports. A number of studies have made estimates of renewable resources by technology (shown in Table 3), which are used in Table 6.

After collecting the initial data for the sub-criteria, the MCDM described in Section 4.5.1 was used to process the data.

In this study, the values of the sub-criteria were in three different formats: namely crisp, fuzzy, and interval numbers. Therefore, the extended TODIM method, which can work with all of these numbers, was used for the analysis. This analysis was performed with the help of MATLAB R2016b. After calculating the profit and loss matrix and normalizing it using Equations (24) and (25), the degree dominance Matrix $(\Delta)$ was obtained using Equation (30), as shown in Table 7. Using the degree dominance matrix and Equation (31), the overall value of each option $A_{i}, \xi\left(A_{i}\right)$ was calculated. The results of the model are presented in Table 8. As can be seen, photovoltaic energy was found to be the best option. This means that solar PV (photovoltaic) is the optimal RER for the production of fertilizer in Iranian farmlands among the four investigated resources, followed by wind power, solar thermal power and biomass power. 
Table 6. Comparison matrix for the Renewable Energy Resource (RER) options under each sub-criterion.

\begin{tabular}{ccccc}
\hline Sub-Criteria & & \multicolumn{2}{c}{ Options } & \\
& Solar (PV) & Biomass & Wind & Solar Thermal \\
\hline Political acceptance & $\mathrm{H}$ & $\mathrm{L}$ & $\mathrm{L}$ & $\mathrm{L}$ \\
Political benefit & $\mathrm{H}$ & $\mathrm{M}$ & $\mathrm{H}$ & $\mathrm{M}$ \\
Sanction & $\mathrm{L}$ & $\mathrm{M}$ & $\mathrm{L}$ & $\mathrm{M}$ \\
Capital Cost (USD/kW) & $750-2000$ & $1609-6400$ & $839-1400$ & $981-4300$ \\
Operation and maintenance (OM) & $10-42$ & $23-99.4$ & $15-60.86$ & $25-95$ \\
Cost (USD/kW/y) & $\mathrm{VH}$ & $\mathrm{L}$ & $\mathrm{VH}$ & $\mathrm{L}$ \\
Local welfare & $\mathrm{VH}$ & $\mathrm{H}$ & $\mathrm{VH}$ & $\mathrm{M}$ \\
Social acceptance & $\mathrm{H}$ & $\mathrm{M}$ & $\mathrm{H}$ & $\mathrm{M}$ \\
Safety of energy system & $\mathrm{H}$ & $\mathrm{L}$ & $\mathrm{H}$ & $\mathrm{H}$ \\
Efficiency $(\%)$ & $12-20$ & $15.4-25$ & 35 & 21 \\
Reliability & $\mathrm{VH}$ & $\mathrm{H}$ & $\mathrm{L}$ & $\mathrm{L}$ \\
Technical maturity & $\mathrm{H}$ & $\mathrm{M}$ & $\mathrm{VH}$ & $\mathrm{L}$ \\
Feasibility & $\mathrm{H}$ & $\mathrm{M}$ & $\mathrm{H}$ & $\mathrm{M}$ \\
Capacity $(\%)$ & 18 & 75 & 30 & 38 \\
Investors' awareness and information & 2130 & 200 & 570 & 2200 \\
Availability (kWh/m $/ \mathrm{y})$ & $\mathrm{H}$ & $\mathrm{L}$ & $\mathrm{L}$ & $\mathrm{M}$ \\
Ease of running on farmland & $40-70$ & 100 & $40-60$ & $15-20$ \\
Emission reduction (g Co 2 eq/kWh) & 21.67 & 38.2 & 6.33 & 4.67 \\
Human toxicity (g 1,4-DBeq/kWh) & $\mathrm{L}$ & $\mathrm{M}$ & $\mathrm{L}$ & $\mathrm{L}$ \\
Legal regulation of activities & $\mathrm{H}$ & $\mathrm{M}$ & $\mathrm{M}$ & $\mathrm{H}$ \\
Legal incentives & & & & \\
\hline
\end{tabular}

Table 7. The dominance degree matrix $(\Delta)$.

\begin{tabular}{ccccc}
\hline Options & Solar $(\mathbf{P V})$ & Biomass & Wind & Solar Thermal \\
\hline Solar $(\mathrm{PV})$ & 0 & -6.233 & -19.229 & -14.637 \\
Biomass & -81.575 & 0 & -65.428 & -32.310 \\
Wind & -32.493 & -12.519 & 0 & -17.238 \\
Solar thermal & -63.228 & -21.768 & -50.650 & 0 \\
\hline
\end{tabular}

Table 8. The ranking of the RER options.

\begin{tabular}{ccc}
\hline Option & Value of Options $\left[\xi\left(A_{i}\right)\right]$ & Rank \\
\hline Solar $(\mathrm{PV})$ & 1 & 1 \\
Biomass & 0 & 4 \\
Wind & 0.8409 & 2 \\
Solar thermal & 0.3137 & 3 \\
\hline
\end{tabular}

\subsection{Sensitivity Analysis}

Since the results obtained from the proposed model depend on the weight assigned to the criteria, a sensitivity analysis was performed to observe the changes in the results when the criteria are weighted differently. This analysis was performed in six scenarios. In each of these six scenarios, the ranking process was repeated with the weight of one of the criteria changed to zero. The results of this sensitivity analysis are presented in Figure 8.

Scenario 1: Changing the weight of the political criterion.

Scenario 2: Changing the weight of the economic criterion.

Scenario 3: Changing the weight of social criterion.

Scenario 4: Changing the weight of the technical criterion.

Scenario 5: Changing the weight of the environmental criterion.

Scenario 6: Changing the weight of the legal criterion. 


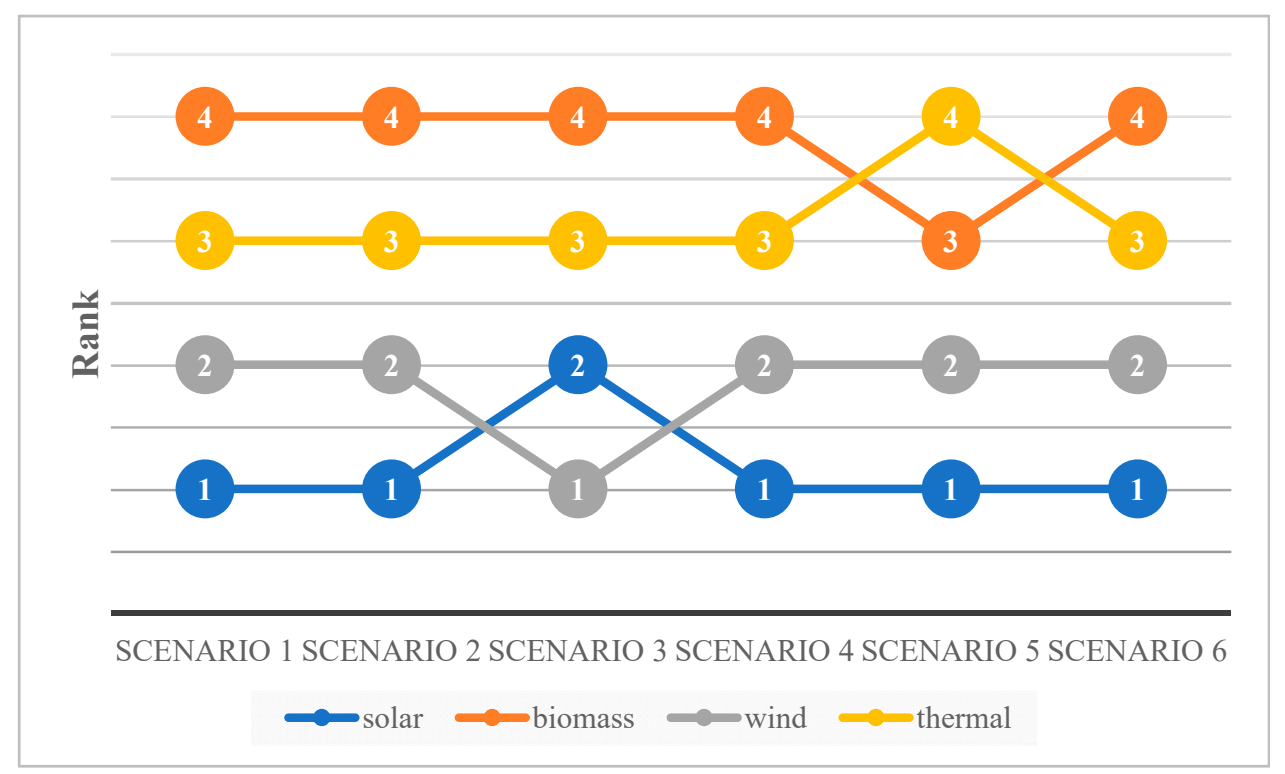

Figure 8. Sensitivity analysis results.

The results of the sensitivity analysis show that, in five of the six scenarios, photovoltaic energy (PV) and wind energy ranked first and second, respectively, and in the other scenario, they have the opposite ranking. Furthermore, in five of the six scenarios, solar thermal and biomass energy were ranked third and fourth, and in the other scenario, they have the opposite ranking.

\subsection{Comparative Analysis}

For the purpose of the comparative analysis, two methods-Simple Additive Weighting (SAW) and TOPSIS - were used to highlight the importance of risk preference in the choosing of the right option. The SAW method is one of the simplest and most commonly used methods for solving MCDM problems. In this method, the option is selected where the sum of its normalized weight values obtained for each option by multiplying the importance weight assigned for each sub-criterion to the option on each sub-criteria is greater than the other options $[49,72]$. The principle of the TOPSIS method is based on the notion that the selected option should have the shortest distance from the ideal positive solution and the maximum distance to the ideal negative solution. These two approaches have been used in various studies to select the best renewable energy resource, including $\mathrm{Wu}$ [49], Mostafaeipour [72], and Lee [51]. A full description of these two methods can be found in Streimikiene [46] and Mostafaeipour [72].

The results of these methods are presented in Table 9. The results of the comparative analysis showed that the compared methods produce the same results as the main method of the study.

Table 9. The results of the different MCDM methods.

\begin{tabular}{ccccc}
\hline Option & Solar $(\mathbf{P V})$ & Biomass & Wind & Solar Thermal \\
\hline Extended TODIM & 1 & 4 & 2 & 3 \\
SAW & 1 & 4 & 2 & 3 \\
TOPSIS & 1 & 4 & 2 & 3 \\
\hline
\end{tabular}

\section{Conclusions}

It is widely accepted that small-scale renewably-powered ammonia production is more sustainable than the production of ammonia by the use of fossil fuels. This paper analyzed, for the first time, the choice of renewable energy resources for on-site ammonia and fertilizer production in farmlands in 
Iran. The four resources considered for this application were photovoltaic, biomass, wind, and solar thermal, which can be prioritized by the use of MCDM methods. With the help of six experts, 20 sub-criteria in six criteria were identified based on the PESTEL analysis, and then their weights were determined by the Fuzzy AHP method. For many real-world decision problems where the presence of ambiguity or uncertainty makes it impossible to use only crisp numbers, one has to find a method with the ability to receive fuzzy, crisp, and interval-type inputs simultaneously and produce a valid output. Therefore, this study used the extended TODIM method for the ranking of the options in terms of the criteria. A sensitivity analysis was also performed to determine the impact of the criteria weights on the ranking of the outcomes. A comparative analysis was also carried out to evaluate the results of the followed approach compared to the other decision-making methods. The results of this study can be summarized as follows:

- It was found that the most important criteria for choosing the suitable renewable resources for on-site fertilizer production in Iranian farmlands are the technological (0.4888), economical (0.1287), and social (0.11) criteria, in that order.

- The results of the rankings showed that the ideal option for the production of ammonia and fertilizers in Iranian farmlands is photovoltaic energy. This result can be attributed to the excellent solar energy potential of Iran, which has 300 sunny days a year on average, and average solar radiation of $2200 \mathrm{kWh} / \mathrm{m}^{2}$. Harvesting even $1 \%$ of the country's total solar energy potential at $10 \%$ efficiency would provide about 9 million megawatts of electricity per day. Furthermore, it has been estimated that the real amount of annual sunlight hours in Iran is more than $2800 \mathrm{~h}$. Solar energy is suitable for most parts of Iran, especially the central part.

- Wind energy, solar thermal energy, and biomass energy were ranked second to fourth, respectively.

- Wind energy is available in the north (the Manjil region), the northeast (the Binalood region), and the southeast (the Zabol region) of Iran. Therefore, we suggest the use wind energy for small-scale renewably-powered ammonia production only for these regions, which have very low risk.

- The sensitivity analysis showed that, in all of the criteria weighting scenarios, photovoltaic energy and wind energy were the top two priorities.

- The results of the comparative analysis showed that the compared methods produced the same results as the main method of the study.

- Investors, farmers and the government can use the results of this research to assess the risk factors and reliability of the resources.

Our suggestions for future works are as follows:

- Using the method of this paper to evaluate renewable energy resources in other regions.

- Using the method to rank and prioritize other options.

- Comparing the results of other methods with the results of this study.

- Using other criteria for the ranking and prioritization.

Author Contributions: A.M.: Conceptualization, Software, Supervision, Writing-Reviewing and Editing, Validation, Data curation. A.S.S.: Writing- Original draft preparation, Visualization, Investigation, Software. S.C.: Methodology, Validation, Reviewing, Editing English. K.T.: Supervision, Writing-Reviewing, Literature Survey and Review, Funding. All authors have read and agreed to the published version of the manuscript.

Funding: This research received no external funding.

Acknowledgments: The authors are thankful to the Institute of Research and Development, Duy Tan University for their kind support; the authors are also grateful to the faculty of Environmental Management, Prince of Songkla University for their help.

Conflicts of Interest: The authors declare that they have no known competing financial interests or personal relationships that could have appeared to influence the work reported in this paper. 


\section{Appendix A}

Table A1. Pairwise matrix (the linguistic evaluations for the sub-criteria) to understand the importance of each sub-criterion for the evaluation of different renewable methods of powering on-site fertilizer production in farmlands.

\begin{tabular}{|c|c|c|c|c|c|c|c|c|c|c|c|c|c|c|c|c|c|c|c|c|}
\hline S.C. & C1.1 & C1.2 & C1.3 & C2.1 & $\mathrm{C} 2.2$ & C3.1 & C3.2 & C3.3 & C4.1 & C4.2 & C4.3 & C4.4 & C4.5 & C4.6 & C4.7 & C4.8 & C5.1 & C5.2 & C6.1 & C6.2 \\
\hline C1.1 & 1 & $\mathrm{VL}^{-1}$ & $\mathrm{~L}^{-1}$ & $\mathrm{H}^{-1}$ & $\mathrm{~L}^{-1}$ & $\mathrm{M}^{-1}$ & $\mathrm{M}^{-1}$ & VL & $\mathrm{L}^{-1}$ & $\mathrm{VH}^{-1}$ & $\mathrm{H}^{-1}$ & $M^{-1}$ & $\mathrm{VL}^{-1}$ & $\mathrm{M}^{-1}$ & $\mathrm{H}^{-1}$ & $\mathrm{~L}^{-1}$ & $\mathrm{H}^{-1}$ & $\mathrm{VL}^{-1}$ & $\mathrm{M}^{-1}$ & VL \\
\hline C1.2 & VL & 1 & $\mathrm{~L}$ & $\mathrm{~L}^{-1}$ & $\mathrm{VL}^{-1}$ & $\mathrm{VL}^{-1}$ & $\mathrm{M}^{-1}$ & VL & $\mathrm{M}^{-1}$ & $\mathrm{~L}^{-1}$ & $\mathrm{VL}^{-1}$ & VL & $\mathrm{VL}^{-1}$ & $\mathrm{~L}^{-1}$ & $\mathrm{H}^{-1}$ & $\mathrm{M}^{-1}$ & $\mathrm{~L}^{-1}$ & $\mathrm{~L}^{-1}$ & VL & $\mathrm{M}^{-1}$ \\
\hline C1.3 & $\mathrm{L}$ & $\mathrm{L}^{-1}$ & 1 & $\mathrm{~L}^{-1}$ & $\mathrm{H}^{-1}$ & $\mathrm{~L}^{-1}$ & $\mathrm{VL}^{-1}$ & $\mathrm{H}$ & VL & $\mathrm{L}^{-1}$ & $\mathrm{H}^{-1}$ & $\mathrm{~L}^{-1}$ & $\mathrm{VL}^{-1}$ & $\mathrm{H}^{-1}$ & $\mathrm{VH}^{-1}$ & $\mathrm{H}$ & $\mathrm{L}^{-1}$ & $\mathrm{~L}^{-1}$ & $\mathrm{~L}^{-1}$ & $\mathrm{VL}^{-1}$ \\
\hline C2.1 & $\mathrm{H}$ & $\mathrm{L}$ & L & 1 & $\mathrm{VL}^{-1}$ & $\mathrm{~L}$ & $\mathrm{H}$ & VL & $\mathrm{VL}^{-1}$ & $\mathrm{H}^{-1}$ & $\mathrm{~L}^{-1}$ & $\mathrm{H}$ & $\mathrm{L}^{-1}$ & L & $\mathrm{H}^{-1}$ & $\mathrm{~L}$ & $\mathrm{H}^{-1}$ & $\mathrm{~L}^{-1}$ & L & $\mathrm{H}$ \\
\hline C2.2 & $\mathrm{L}$ & VL & $\mathrm{H}$ & VL & 1 & $\mathrm{VL}^{-1}$ & $\mathrm{M}^{-1}$ & $\mathrm{~L}^{-1}$ & L & $\mathrm{H}^{-1}$ & $\mathrm{VH}^{-1}$ & $\mathrm{H}$ & $\mathrm{L}^{-1}$ & $\mathrm{M}^{-1}$ & $\mathrm{H}^{-1}$ & $\mathrm{~L}$ & $\mathrm{H}^{-1}$ & $\mathrm{M}^{-1}$ & $\mathrm{H}$ & $\mathrm{H}$ \\
\hline C3.1 & $\mathrm{M}$ & VL & $\mathrm{L}$ & $\mathrm{L}^{-1}$ & VL & 1 & $\mathrm{~L}^{-1}$ & VL & $\mathrm{L}$ & $\mathrm{L}^{-1}$ & $\mathrm{~L}^{-1}$ & $\mathrm{~L}$ & $\mathrm{H}^{-1}$ & $\mathrm{H}^{-1}$ & $\mathrm{VH}^{-1}$ & $\mathrm{~L}$ & $\mathrm{VH}^{-1}$ & $\mathrm{~L}^{-1}$ & $\mathrm{~L}^{-1}$ & $M^{-1}$ \\
\hline C 3.2 & $\mathrm{M}$ & $\mathrm{M}$ & VL & $\mathrm{H}^{-1}$ & $\mathrm{M}$ & $\mathrm{L}$ & 1 & $\mathrm{~L}$ & $\mathrm{~L}$ & $\mathrm{H}^{-1}$ & $\mathrm{H}^{-1}$ & $\mathrm{~L}^{-1}$ & $\mathrm{H}^{-1}$ & $\mathrm{~L}^{-1}$ & $\mathrm{H}^{-1}$ & $\mathrm{~L}^{-1}$ & $\mathrm{~L}^{-1}$ & $\mathrm{VL}^{-1}$ & $\mathrm{H}^{-1}$ & $\mathrm{H}^{-1}$ \\
\hline C 3.3 & $\mathrm{VL}^{-1}$ & $\mathrm{VL}^{-1}$ & $\mathrm{H}^{-1}$ & $\mathrm{VL}^{-1}$ & $\mathrm{~L}$ & $\mathrm{VL}^{-1}$ & $\mathrm{~L}^{-1}$ & 1 & VL & $\mathrm{L}^{-1}$ & $\mathrm{VL}^{-1}$ & $\mathrm{VL}^{-1}$ & $\mathrm{~L}^{-1}$ & VL & $\mathrm{H}^{-1}$ & $\mathrm{~L}$ & $\mathrm{H}^{-1}$ & $\mathrm{~L}^{-1}$ & $\mathrm{H}^{-1}$ & L \\
\hline C4.1 & $\mathrm{L}$ & $\mathrm{M}$ & $\mathrm{VL}^{-1}$ & VL & $\mathrm{L}^{-1}$ & $\mathrm{~L}^{-1}$ & $\mathrm{~L}^{-1}$ & $\mathrm{VL}^{-1}$ & 1 & $\mathrm{~L}^{-1}$ & $\mathrm{M}^{-1}$ & $\mathrm{~L}$ & $\mathrm{VL}^{-1}$ & $\mathrm{~L}^{-1}$ & $\mathrm{H}^{-1}$ & $\mathrm{H}$ & $\mathrm{H}^{-1}$ & $\mathrm{~L}^{-1}$ & $\mathrm{~L}^{-1}$ & $\mathrm{M}^{-1}$ \\
\hline C4.2 & $\mathrm{VH}$ & $\mathrm{L}$ & L & $\mathrm{H}$ & $\mathrm{H}$ & $\mathrm{L}$ & $\mathrm{H}$ & L & $\mathrm{L}$ & 1 & VL & $\mathrm{H}$ & $\mathrm{L}^{-1}$ & $\mathrm{~L}^{-1}$ & $\mathrm{H}^{-1}$ & $\mathrm{VH}$ & $\mathrm{VL}^{-1}$ & $\mathrm{M}^{-1}$ & $\mathrm{VL}^{-1}$ & $\mathrm{H}$ \\
\hline C4.3 & $\mathrm{H}$ & VL & $\mathrm{H}$ & $\mathrm{L}$ & $\mathrm{VH}$ & $\mathrm{L}$ & $\mathrm{H}$ & VL & $\mathrm{M}$ & $\mathrm{VL}^{-1}$ & 1 & $\mathrm{H}$ & $\mathrm{M}^{-1}$ & $\mathrm{H}^{-1}$ & $\mathrm{VH}^{-1}$ & $\mathrm{H}$ & $\mathrm{L}^{-1}$ & $\mathrm{~L}^{-1}$ & $\mathrm{M}^{-1}$ & $\mathrm{~L}$ \\
\hline C4.4 & $\mathrm{M}$ & $\mathrm{VL}^{-1}$ & $\mathrm{~L}$ & $\mathrm{H}^{-1}$ & $\mathrm{H}^{-1}$ & $\mathrm{~L}^{-1}$ & $\mathrm{~L}$ & VL & $\mathrm{L}^{-1}$ & $\mathrm{H}^{-1}$ & $\mathrm{H}^{-1}$ & 1 & $\mathrm{H}^{-1}$ & $\mathrm{H}^{-1}$ & $\mathrm{VH}^{-1}$ & VL & $\mathrm{H}^{-1}$ & $\mathrm{H}^{-1}$ & $\mathrm{~L}^{-1}$ & $\mathrm{~L}$ \\
\hline C4.5 & VL & VL & VL & $\mathrm{L}$ & $\mathrm{L}$ & $\mathrm{H}$ & $\mathrm{H}$ & $\mathrm{L}$ & VL & $\mathrm{L}$ & $\mathrm{M}$ & $\mathrm{H}$ & 1 & $\mathrm{H}$ & $\mathrm{M}^{-1}$ & $\mathrm{~L}$ & $\mathrm{M}^{-1}$ & VL & $\mathrm{VL}^{-1}$ & VL \\
\hline C4.6 & $\mathrm{M}$ & $\mathrm{L}$ & $\mathrm{H}$ & $\mathrm{L}^{-1}$ & $\mathrm{M}$ & $\mathrm{H}$ & $\mathrm{L}$ & $\mathrm{VL}^{-1}$ & $\mathrm{~L}$ & $\mathrm{~L}$ & $\mathrm{H}$ & $\mathrm{H}$ & $\mathrm{H}^{-1}$ & 1 & $\mathrm{H}^{-1}$ & $\mathrm{~L}$ & $\mathrm{VL}^{-1}$ & $\mathrm{M}^{-1}$ & $\mathrm{VL}^{-1}$ & $\mathrm{M}^{-1}$ \\
\hline C4.7 & $\mathrm{H}$ & $\mathrm{H}$ & $\mathrm{VH}$ & $\mathrm{H}$ & $\mathrm{H}$ & $\mathrm{VH}$ & $\mathrm{H}$ & $\mathrm{H}$ & $\mathrm{H}$ & $\mathrm{H}$ & $\mathrm{VH}$ & $\mathrm{VH}$ & $\mathrm{M}$ & $\mathrm{H}$ & 1 & $\mathrm{VH}$ & $\mathrm{M}^{-1}$ & VL & $\mathrm{L}$ & $\mathrm{H}$ \\
\hline C4.8 & $\mathrm{L}$ & $\mathrm{M}$ & $\mathrm{H}^{-1}$ & $\mathrm{~L}^{-1}$ & $\mathrm{~L}^{-1}$ & $\mathrm{~L}^{-1}$ & $\mathrm{~L}$ & $\mathrm{~L}^{-1}$ & $\mathrm{H}^{-1}$ & $\mathrm{VH}^{-1}$ & $\mathrm{H}^{-1}$ & $\mathrm{VL}^{-1}$ & $\mathrm{~L}^{-1}$ & $\mathrm{~L}^{-1}$ & $\mathrm{VH}^{-1}$ & 1 & $\mathrm{VH}^{-1}$ & $\mathrm{H}^{-1}$ & $\mathrm{H}^{-1}$ & $\mathrm{VL}^{-1}$ \\
\hline C5.1 & $\mathrm{H}$ & $\mathrm{L}$ & L & $\mathrm{H}$ & $\mathrm{H}$ & $\mathrm{VH}$ & $\mathrm{L}$ & $\mathrm{H}$ & $\mathrm{H}$ & VL & $\mathrm{L}$ & $\mathrm{H}$ & $\mathrm{M}$ & VL & $\mathrm{M}$ & VH & 1 & $\mathrm{~L}$ & $\mathrm{M}^{-1}$ & L \\
\hline C5.2 & VL & $\mathrm{L}$ & $\mathrm{L}$ & $\mathrm{L}$ & $\mathrm{M}$ & $\mathrm{L}$ & VL & $\mathrm{L}$ & $\mathrm{L}$ & $\mathrm{M}$ & $\mathrm{L}$ & $\mathrm{H}$ & $\mathrm{VL}^{-1}$ & $\mathrm{M}$ & $\mathrm{VL}^{-1}$ & $\mathrm{H}$ & $\mathrm{L}^{-1}$ & 1 & VL & $\mathrm{L}$ \\
\hline C6.1 & $\mathrm{M}$ & $\mathrm{VL}^{-1}$ & $\mathrm{~L}$ & $\mathrm{~L}^{-1}$ & $\mathrm{H}^{-1}$ & $\mathrm{~L}$ & $\mathrm{H}$ & $\mathrm{H}$ & $\mathrm{L}$ & VL & $\mathrm{M}$ & $\mathrm{L}$ & VL & VL & $\mathrm{L}^{-1}$ & $\mathrm{H}$ & $\mathrm{M}$ & $\mathrm{VL}^{-1}$ & 1 & $\mathrm{~L}$ \\
\hline C6.2 & $\mathrm{VL}^{-1}$ & M & VL & $\mathrm{H}^{-1}$ & $\mathrm{H}^{-1}$ & $\mathrm{M}$ & $\mathrm{H}$ & $\mathrm{L}^{-1}$ & $\mathrm{M}$ & $\mathrm{H}^{-1}$ & $\mathrm{~L}^{-1}$ & $\mathrm{~L}^{-1}$ & $\mathrm{VL}^{-1}$ & $\mathrm{M}$ & $\mathrm{H}^{-1}$ & VL & $\mathrm{L}^{-1}$ & $\mathrm{~L}^{-1}$ & $\mathrm{~L}^{-1}$ & 1 \\
\hline
\end{tabular}

Inverse of VL: VL-1. Inverse of L: L-1. Inverse of M: M-1. Inverse of H: H-1. Inverse of VH: VH-1. 


\section{References}

1. Amer, M.; Daim Tugrul, U. Selection of renewable energy technologies for a developing county: A case of Pakistan. Energy Sustain. Dev. 2011, 15, 420-435. [CrossRef]

2. Kumar, S.S.; Himabindu, V. Hydrogen production by PEM water electrolysis-A review. Mater. Sci. Technol. 2019, 2, 442-454.

3. Ramazankhani, M.E.; Mostafaeipour, A.; Hosseininasab, H.; Fakhrzad, M.B. Feasibility of geothermal power assisted hydrogen production in Iran. Int. J. Hydrogen Energy 2016, 41, 18351-18369. [CrossRef]

4. Energy Information Administration. Available online: https://www.eia.gov/ (accessed on 15 September 2019).

5. Sedaghat, A.; Hassanzadeh, A.; Jamali, J.; Mostafaeipour, A.; Chen, W.H. Determination of rated wind speed for maximum annual energy production of variable speed wind turbines. Appl. Energy 2017, 205, 781-789. [CrossRef]

6. Statista. Available online: https://www.statista.com/ (accessed on 1 November 2019).

7. Sánchez, A.; Martín, M. Scale up and scale down issues of renewable ammonia plants: Towards modular design. Sustain. Prod. Consum. 2018, 16, 176-192. [CrossRef]

8. Alfian, M.; Purwanto, W.W. Multi-objective optimization of green urea production. Energy Sci. Eng. 2019, 7, 292-304. [CrossRef]

9. Arora, P.; Hoadley, A.F.; Mahajani, S.M.; Ganesh, A. Multi-objective optimization of biomass based ammonia production-Potential and perspective in different countries. J. Clean. Prod. 2017, 148, 363-374. [CrossRef]

10. Bicer, Y.; Dincer, I.; Zamfirescu, C.; Vezina, G.; Raso, F. Comparative life cycle assessment of various ammonia production methods. J. Clean. Prod. 2016, 135, 1379-1395. [CrossRef]

11. Du, Z.; Denkenberger, D.; Pearce, J.M. Solar photovoltaic powered on-site ammonia production for nitrogen fertilization. Solar Energy 2015, 122, 562-568. [CrossRef]

12. Morgan, E.; Manwell, J.; McGowan, J. Wind-powered ammonia fuel production for remote islands: A case study. Renew. Energy 2014, 72, 51-61. [CrossRef]

13. Casallas, C.; Dincer, I. Assessment of an integrated solar hydrogen system for electrochemical synthesis of ammonia. Int. J. Hydrogen Energy 2017, 42, 21495-21500. [CrossRef]

14. Tallaksen, J.; Bauer, F.; Hulteberg, C.; Reese, M.; Ahlgren, S. Nitrogen fertilizers manufactured using wind power: Greenhouse gas and energy balance of community-scale ammonia production. J. Clean. Prod. 2015, 107, 626-635. [CrossRef]

15. Palys, M.J.; Allman, A.; Daoutidis, P. Exploring the benefits of modular renewable-powered ammonia production: A supply chain optimization study. Ind. Eng. Chem. Res. 2019, 58, 5898-5908. [CrossRef]

16. Büyüközkan, G.; Güleryüz, S. Evaluation of renewable energy resources in turkey using an integrated MCDM approach with linguistic interval fuzzy preference relations. Energy 2017, 123, 149-163. [CrossRef]

17. Bicer, Y.; Dincer, I. Life cycle environmental impact assessments and comparisons of alternative fuels for clean vehicles. Resour. Conserv. Recycl. 2018, 132, 141-157. [CrossRef]

18. Canada, F. Fertilizer Canada's Response to COVID-19. Available online: https://fertilizercanada.ca/ (accessed on 15 November 2019).

19. Razon, L.F. Reactive nitrogen: A perspective on its global impact and prospects for its sustainable production. Sustain. Prod. Consum. 2018, 15, 35-48. [CrossRef]

20. Ju, X.; Gu, B.; Wu, Y.; Galloway, J.N. Reducing China's fertilizer use by increasing farm size. Glob. Environ. Chang. 2016, 41, 26-32. [CrossRef]

21. FAO of UN. Available online: http://www.fao.org/home/en/ (accessed on 6 December 2019).

22. Xu, D.; Lv, L.; Ren, X.; Ren, J.; Dong, L. Route selection for low-carbon ammonia production: A sustainability prioritization framework based-on the combined weights and projection ranking by similarity to referencing vector method. J. Clean. Prod. 2018, 193, 263-276. [CrossRef]

23. Tribune, F. Financial Tribune. Available online: https://financialtribune.com (accessed on 14 January 2020).

24. World Bank Open Data. Available online: https://data.worldbank.org (accessed on 19 November 2019).

25. Frattini, D.; Cinti, G.; Bidini, G.; Desideri, U.; Cioffi, R.; Jannelli, E. A system approach in energy evaluation of different renewable energies sources integration in ammonia production plants. Renew. Energy 2016, 99, 472-482. [CrossRef] 
26. American Institute of Chemical Engineers. Available online: https://www.aiche.org/ (accessed on 5 January 2020).

27. Bicer, Y.; Dincer, I.; Vezina, G.; Raso, F. Impact assessment and environmental evaluation of various ammonia production processes. In Towards 100\% Renewable Energy, Techniques, Costs and Regional Case-Studies; Tanay, S.U., Ed.; Springer: Cham, Switzerland, 2017.

28. Esteves, N.B.; Sigal, A.; Leiva, E.P.; Rodriguez, C.R.; Cavalcante, F.S.; de Lima, L.C. Wind and solar hydrogen for the potential production of ammonia in the state of Ceará-Brazil. Int. J. Hydrogen Energy 2015, 40, 9917-9923. [CrossRef]

29. Martket Publishers. Available online: https://marketpublishers.com/ (accessed on 9 January 2020).

30. Bicer, Y.; Dincer, I. Evaluation of Renewable and Conventional Ammonia as a Potential Solution. In Towards 100\% Renewable Energy, Techniques, Costs and Regional Case-Studies; Tanay, S.U., Ed.; Springer: Cham, Switzerland, 2017.

31. Wang, L.; Xia, M.; Wang, H.; Huang, K.; Qian, C.; Maravelias, C.T.; Ozin, G.A. Greening ammonia toward the solar ammonia refinery. Joule 2018, 2, 1055-1074. [CrossRef]

32. Saboo, T.; Quadrelli, E.A. Photoproduction of ammonia. In Studies in Surface Science and Catalysis; Elsevier: Amsterdam, The Netherlands, 2019; Volume 178, pp. 47-63.

33. Iran Acid, The Acid Trading Center. Available online: http://iran-asid.ir/ (accessed on 3 February 2020).

34. Azeem, B.; KuShaari, K.; Man, Z.B.; Basit, A.; Thanh, T.H. Review on materials \& methods to produce controlled release coated urea fertilizer. J. Control Release 2014, 181, 11-21. [PubMed]

35. Bhandari, R.; Trudewind, C.A.; Zapp, P. Life cycle assessment of hydrogen production via electrolysis-A review. J. Clean. Prod. 2014, 85, 151-163. [CrossRef]

36. Acar, C.; Dincer, I. Review and evaluation of hydrogen production options for better environment. J. Clean. Prod. 2019, 218, 835-849. [CrossRef]

37. Chi, J.; Yu, H. Water electrolysis based on renewable energy for hydrogen production. Chin. J. Catal. 2018, 39, 390-394. [CrossRef]

38. Kovač, A.; Marciuš, D.; Budin, L. Solar hydrogen production via alkaline water electrolysis. Int. J. Hydrogen Energy 2019, 44, 9841-9848. [CrossRef]

39. Hosseini, S.E.; Andwari, A.M.; Wahid, M.A.; Bagheri, G. A review on green energy potentials in Iran. Renew. Sustain. Energy Rev. 2013, 27, 533-545. [CrossRef]

40. Najafi, G.; Ghobadian, B.; Mamat, R.; Yusaf, T.; Azmi, W.H. Solar energy in Iran: Current state and outlook. Renew. Sustain. Energy Rev. 2015, 49, 931-942. [CrossRef]

41. Aghahosseini, A.; Bogdanov, D.; Ghorbani, N.; Breyer, C. Analysis of $100 \%$ renewable energy for Iran in 2030: Integrating solar PV, wind energy and storage. Int. J. Environ. Sci. Technol. 2018, 15, 17-36. [CrossRef]

42. Available online: http://moe.gov.ir (accessed on 5 March 2020).

43. Strantzali, E.; Aravossis, K. Decision making in renewable energy investments: A review. Renew. Sustain. Energy Rev. 2016, 55, 885-898. [CrossRef]

44. Troldborg, M.; Heslop, S.; Hough, R.L. Assessing the sustainability of renewable energy technologies using multi-criteria analysis: Suitability of approach for national-scale assessments and associated uncertainties. Renew. Sustain. Energy Rev. 2014, 39, 1173-1184. [CrossRef]

45. Al Garni, H.; Kassem, A.; Awasthi, A.; Komljenovic, D.; Al-Haddad, K. A multicriteria decision making approach for evaluating renewable power generation sources in Saudi Arabia. Sustain. Energy Technol. Assess. 2016, 16, 137-150. [CrossRef]

46. Streimikiene, D.; Balezentis, T.; Krisciukaitienè, I.; Balezentis, A. Prioritizing sustainable electricity production technologies: MCDM approach. Renew. Sustain. Energy Rev. 2012, 16, 3302-3311. [CrossRef]

47. Haddad, B.; Liazid, A.; Ferreira, P. A multi-criteria approach to rank renewables for the Algerian electricity system. Renew. Energy 2017, 107, 462-472. [CrossRef]

48. Zadeh, L.A. Fuzzy sets. Inf. Control 1965, 8, 338-353. [CrossRef]

49. Wu, Y.; Xu, C.; Zhang, T. Evaluation of renewable power sources using a fuzzy MCDM based on cumulative prospect theory: A case in China. Energy 2018, 147, 1227-1239. [CrossRef]

50. Çolak, M.; Kaya, İ. Prioritization of renewable energy alternatives by using an integrated fuzzy MCDM model: A real case application for Turkey. Renew. Sustain. Energy Rev. 2017, 80, 840-853. [CrossRef]

51. Lee, H.C.; Chang, C.T. Comparative analysis of MCDM methods for ranking renewable energy sources in Taiwan. Renew. Sustain. Energy Rev. 2018, 92, 883-896. [CrossRef] 
52. Kheybari, S.; Rezaie, F.M.; Naji, S.A.; Najafi, F. Evaluation of energy production technologies from biomass using analytical hierarchy process: The case of Iran. J. Clean. Prod. 2019, 232, 257-265. [CrossRef]

53. The World Wind Energy Association (WWEA). Available online: https://wwindea.org/ (accessed on 5 February 2020).

54. Goudarzi, H.; Mostafaeipour, A. Energy saving evaluation of passive systems for residential buildings in hot and dry regions. Renew. Sustain. Energy Rev. 2017, 68, 432-446. [CrossRef]

55. Sherbafian, N. Estimation of the technical and economic potential of thermal solar energy in Iran: A solution for the sustainable development of solar energy. Quart. J. Energy Econ. 2008, 4, 53.

56. Dale, C. The UK tour-operating industry: A competitive analysis. J. Vacat. Mark. 2000, 6, 357-367. [CrossRef]

57. Richardson, J.V., Jr. The library and information economy in Turkmenistan. IFLA 2006, 32, 131-139. [CrossRef]

58. Yüksel, I. Developing a multi-criteria decision making model for PESTEL analysis. IJBM 2012, 7, 52. [CrossRef]

59. Heo, E.; Kim, J.; Cho, S. Selecting hydrogen production methods using fuzzy analytic hierarchy process with opportunities, costs, and risks. Int. J. Hydrogen Energy 2012, 37, 17655-17662. [CrossRef]

60. Ijadi, M.A.; Mosavi, A.; Rabczuk, T.; Zavadskas, E. Renewable energy technology selection problem using integrated h-swara-multimoora approach. Sustainability 2018, 10, 4481. [CrossRef]

61. Ren, J.; Sovacool, B.K. Prioritizing low-carbon energy sources to enhance China's energy security. Energy Convers. Manag. 2015, 92, 129-136. [CrossRef]

62. Štreimikienè, D.; Šliogerienè, J.; Turskis, Z. Multi-criteria analysis of electricity generation technologies in Lithuania. Renew. Energy 2016, 85, 148-156. [CrossRef]

63. Kahraman, C.; Kaya, İ.; Cebi, S. A comparative analysis for multiattribute selection among renewable energy alternatives using fuzzy axiomatic design and fuzzy analytic hierarchy process. Energy 2009, 34, 1603-1616. [CrossRef]

64. Ren, J.; Toniolo, S. Life cycle sustainability decision-support framework for ranking of hydrogen production pathways under uncertainties: An interval multi-criteria decision making approach. J. Clean. Prod. 2018, 175, 222-236. [CrossRef]

65. Stougie, L.; Giustozzi, N.; van der Kooi, H.; Stoppato, A. Environmental, economic and exergetic sustainability assessment of power generation from fossil and renewable energy sources. Int. J. Energy Res. 2018, 42, 2916-2926. [CrossRef]

66. BarghNews. Available online: https://barghnews.com/ (accessed on 9 February 2020).

67. Haratian, M.; Tabibi, P.; Sadeghi, M.; Vaseghi, B.; Poustdouz, A. A renewable energy solution for stand-alone power generation: A case study of KhshU Site-Iran. Renew. Energy 2018, 125, 926-935. [CrossRef]

68. Aryanpur, V.; Atabaki, M.S.; Marzband, M.; Siano, P.; Ghayoumi, K. An overview of energy planning in Iran and transition pathways towards sustainable electricity supply sector. Renew. Sustain. Energy Rev. 2019, 112, 58-74. [CrossRef]

69. Chauhan, A.; Singh, A. A hybrid multi-criteria decision making method approach for selecting a sustainable location of healthcare waste disposal facility. J. Clean. Prod. 2016, 139, 1001-1010. [CrossRef]

70. Chang, D.Y. Applications of the extent analysis method on fuzzy AHP. Eur. J. Operat. Res. 1996, 95, 649-655. [CrossRef]

71. Fan, Z.P.; Zhang, X.; Chen, F.D.; Liu, Y. Extended TODIM method for hybrid multiple attribute decision making problems. Knowl. Based Syst. 2013, 42, 40-48. [CrossRef]

72. Mostafaeipour, A.; Sadeghi, S.A. Investigation of solar energy utilization for production of hydrogen and sustainable chemical fertilizer: A case study. Int. J. Energy Res. 2019, 43, 8314-8336. [CrossRef]

(C) 2020 by the authors. Licensee MDPI, Basel, Switzerland. This article is an open access article distributed under the terms and conditions of the Creative Commons Attribution (CC BY) license (http://creativecommons.org/licenses/by/4.0/). 